\title{
FACTOR ACCUMUlation AND Trade: \\ DYNAMIC COMPARATIVE ADVANTAGE WITH ENDOGENOUS PHYSICAL AND HUMAN CAPITAL
}

by

Eric W. Bond, Kathleen Trask, and Ping Wang

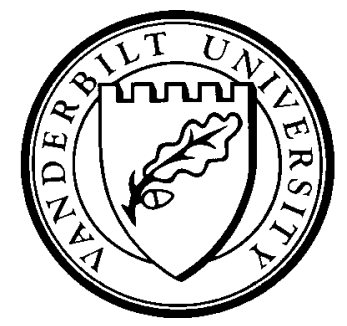

Working Paper No. 00-W31

October 1996

Revised August 2000

\section{DEPARTMENT OF ECONOMICS \\ VANDERBILT UNIVERSITY \\ NASHVILLE, TN 37235}

www.vanderbilt.edu/econ 


\title{
Factor Accumulation and Trade: Dynamic Comparative Advantage with Endogenous Physical and Human Capital
}

\author{
Eric W. Bond \\ Department of Economics \\ The Pennsylvania State University \\ Kathleen Trask \\ Department of Economics \\ University of Kentucky \\ Ping Wang \\ Department of Economics \\ Vanderbilt University \\ First Version: October 1996 \\ This Version: August 2000
}

\begin{abstract}
This paper develops a two country endogenous growth model with accumulation of both physical and human capital. We establish the existence of two country balanced growth equilibria in which physical and human capital grow at the same rate in each country but physical/human capital ratios differ across countries. These balanced growth equilibria satisfy a static and dynamic version of the Heckscher-Ohlin theorem. We also show the existence of unbalanced growth equilibria in which the static and dynamic Heckscher-Ohlin theorems can be violated. The multiplicity of paths with international trade results from the intertemporal no arbitrage condition in cases where trade results in an equalization of factor prices across countries.
\end{abstract}

Keywords: Trade Patterns, Factor Accumulation, Endogenous Growth

JEL Classification: D90, F11, F43, O41.

Acknowledgement: We have benefitted from comments and suggestions from seminar participants at Indiana, National Chengchi, Pittsburgh, Rochester, St. Louis Fed, the (Spring) 1997 Midwest Macroeconomics Conference at Penn State, the (Fall) 1997 Midwest Mathematical Economical Economics Conference at Northwestern, the 1998 AEA Meetings in Chicago and the Dynamics, Economic Growth and International Trade Conference at Helsingor in Denmark. Needless to say, the usual disclaimer applies.

Address for Correspondence: Eric W. Bond, Department of Economics, Penn State University, University Park, PA 16802; e-mail: ewb1@psu.edu. 


\section{Introduction}

Recent work in growth theory has provided a compelling demonstration that human capital accumulation plays an important role, distinct from that of physical capital, in explaining differences in cross-country income growth. ${ }^{1}$ However, theoretical analysis of models of endogenous growth with physical and human capital accumulation have primarily focused on the case of closed economies. The purpose of this paper is to analyze the interactions between physical and human capital accumulation in open economies, and to illustrate how the distinction between closed and open economies can be important for analyzing the dynamics of factor accumulation. In closed economy endogenous growth models (e.g., Rebelo (1991), Caballé and Santos (1993), and Bond, Wang, and Yip (1996)), the convergence of relative factor supplies results from the fact that a country with a relatively large supply of physical capital will have a relatively higher return on human capital, and hence a higher relative accumulation of human capital. In contrast, an open economy can make up for the scarcity of a particular factor by importing goods that use the scarce factor relatively intensively. In fact, if the conditions for factor price equalization are met local factor rewards will be independent of local factor supplies and hence will not serve as a force toward convergence in relative factor supplies.

Ventura (1997) has used the factor price equalization property in a model of growth with accumulation of physical capital to argue that East Asian countries could experience high rates of physical capital accumulation without experiencing diminishing returns because they could change the composition of their production toward more capital intensive goods. Our analysis is intended to address the question of how open economies choose to allocate their capital accumulation between physical and human capital accumulation, and how this decision affects the pattern of trade over time. We consider a three sector model endogenous growth model with two traded goods (the consumption and investment good) and a non-traded good (the education good). This framework will be used to address two fundamental issues in the theory of trade and growth: (i) how the presence of international trade influences the factor accumulation process in 
an economy with sustained growth and, (ii) how the perpetual evolution of reproducible factor supplies determines both static and dynamic comparative advantage and therefore affects the patterns of trade in both the short and long run. The assumption of two traded goods and two traded factors allows the relative supplies of physical and human capital to play a role in determining the pattern of trade, while the assumption of two accumulating factors allows both the rate and composition of factor accumulation to be influenced by world prices. We thus synthesize the closed economy models of physical and human capital accumulation with the dynamic Heckscher-Ohlin models (surveyed in Smith (1984)), which have focused almost exclusively on the case in which only physical capital endogenously accumulates.

It is natural in this open economy framework to center our discussion on the determinants of comparative advantage in the short and long run. In the spirit of the static Heckscher-Ohlin model, we will assume that all countries have identical tastes and technologies, so that the only differences across countries are in their initial endowments (in efficiency units) physical and human capital. These assumptions will ensure that the autarkic steady states of all countries will be the same, so that the dynamics of comparative advantage are determined by how factor abundance affects the pattern of trade during the transition to the steady state when initial endowments are away from their autarkic steady states. ${ }^{2}$ We will examine two types of results relating factor abundance to the pattern of trade. The first is the familiar static Heckscher-Ohlin theorem, which relates factor supplies to the pattern of comparative advantage. Letting $\mathrm{k}^{\mathrm{i}}(\mathrm{t}) \equiv \mathrm{K}^{\mathrm{i}}(\mathrm{t}) / \mathrm{H}^{\mathrm{i}}(\mathrm{t})$ denote the aggregate physical/human capital ratio in country $i$ at time $t$, this theorem can be expressed as:

(Static H-O): If $k^{A}(t)>k^{B}(t)$ then

(a) country A exports the capital intensive traded good at time $t$.

(b) country A has a lower price of the capital intensive good and lower return on physical capital in under autarky

In a static model with two traded goods, the capital abundant country will produce relatively more of the capital intensive good at a given price. If tastes are identical and homothetic across countries, this will result 
in a lower autarkic price of the capital intensive good and an export of capital intensive goods with free trade. Since the model we are examining is a dynamic one, we would also like to know whether initial factor endowments can be used to predict future patterns of trade. This suggests the following definition of a dynamic Heckscher-Ohlin theorem :

$$
\begin{aligned}
& \text { (Dynamic H-O): If } k^{A}(t)>k^{B}(t), \text { then } k^{A}\left(t^{\prime}\right) \geq k^{B}\left(t^{\prime}\right) \text { for } t^{\prime}>t \text { and the capital abundant country } \\
& \text { will not export the labor intensive good for } t^{\prime}>t .
\end{aligned}
$$

The statement of this theorem allows for the possibility that all countries converge to the same factor endowment ratio, so that trade disappears asymptotically, although this is not necessarily a long run property of dynamic models with identical preferences and technologies. ${ }^{3}$ Notably, the Ventura (1997) model satisfies both the static and dynamic $\mathrm{H}-\mathrm{O}$ theorems regardless of whether relative factor endowments are convergent or non-convergent.

The dynamic model of physical and human capital accumulation that we examine can generate violations of both the static and dynamic Heckscher-Ohlin theorems. We show that a violation of part (a) of the static Heckscher-Ohlin theorem can arise if the growth rate of human capital differs across countries. The production of human capital requires the withdrawal of resources from the production of traded goods. Letting $\tilde{\mathrm{k}}^{\mathrm{i}}$ denote the relative factor supply available to produce traded goods, we could have $\mathrm{k}^{\mathrm{A}}>\mathrm{k}^{\mathrm{B}}$ but $\tilde{\mathrm{k}}^{\mathrm{A}}<\tilde{\mathrm{k}}^{\mathrm{B}}$ when rates of human capital accumulation differ across countries. Since the latter ratio determines the relative production of traded goods, this would result in a violation of the Heckscher-Ohlin theorem. A violation of part (b) of the static Heckscher-Ohlin theorem can also arise in the dynamic model because of intertemporal linkages. The intertemporal linkage arises because the concavity of the value function implies that the price of the investment good relative to the investment good will be non-increasing in $\mathrm{k}$. If the investment good uses physical capital intensively in its production, then the physical capital intensive good is cheaper in autarky in the capital abundant economy. However, if the investment good is human capital intensive a lower price for the investment good in the capital abundant economy would imply 
a lower price for the human capital intensive good. We show that in this case the autarky relative prices will be independent of the local factor supplies and (b) of the static Heckscher-Ohlin theorem will fail.

The potential failure of the dynamic version of the $\mathrm{H}-\mathrm{O}$ theorem arises in cases where international trade results in the equalization of factor prices (for efficiency units of factors) across countries . The intertemporal no-arbitrage condition for factor accumulation implies that along any optimal path, the net rates of return (with an explicit account of capital gains) to investment in physical and human capital are equalized, which makes investors indifferent between accumulation of physical and human capital at the margin. Factor price equalization ensures that paths with alternative compositions of factor accumulation are utility equivalent, because the open economy can increase the production of the good that is intensive in the use of the most rapidly accumulating factor. These two elements lead to a multiplicity of unbalanced growth paths for capital accumulation, which is consistent with a variety of different growth experiences across countries and a lack of convergence in relative factor supplies across countries. The constraint on possible growth experiences is provided by the requirement that the economy remain incompletely specialized.

The plan of the paper is as follows. Section 2 presents the closed economy version of the model and establishes the existence, uniqueness, and saddle path stability of the closed economy balanced growth path. ${ }^{4}$ In Section 3 we analyze a two country, open economy version of the model and establish that balanced growth for the world economy can be consistent with either balanced or unbalanced growth for the individual countries. Along an open economy balanced growth path, relative factor supplies will remain constant, the dynamic and static $\mathrm{H}-\mathrm{O}$ theorems will hold, and the volume of trade will grow at the growth rate of factor supplies. However, we also show that the same range of relative factor supplies is also consistent with unbalanced growth paths in which physical and human capital grow at different rates and in such a equilibrium both the static and dynamic versions of the $\mathrm{H}-\mathrm{O}$ theorem can fail. In Section 4, we examine the 
nature of gains from trade and establish the conditions under which (b) of the static H-O theorem will hold. In Section 5, we summarize the results and discuss future extensions of the research.

\section{The Integrated World Equilibrium}

We begin by considering the solution to the closed economy version of a three sector model of endogenous growth in which there are two reproducible factors of production, physical capital $(\mathrm{K})$ and human capital $(\mathrm{H})$. We establish conditions under which there will exist a unique, stable equilibrium characterized by a balanced growth path (BGP) in which consumption and the stocks of physical and human capital grow at a common rate. The closed economy framework can be thought of as representing the equilibrium for the world economy if factors of production were freely mobile across countries possessing identical preferences and technologies. Following Dixit and Norman (1980), we will refer to this as the solution of the integrated world equilibrium (IWE). In the next section, we will analyze the conditions under which this IWE can be duplicated through international trade in the consumption and investment goods between countries.

\subsection{The Model}

The three sectors will be referred to as the investment goods sector, $\mathrm{X}$, the education sector, $\mathrm{Y}$, and the consumption goods sector, $\mathrm{Z}$. The model thus generalizes the two sector endogenous growth models studied by Caballé and Santos (1993) and Bond, Wang, and Yip (1996) in which consumption and investment goods are treated as perfect substitutes. All sectors are assumed to have production functions exhibiting constant returns to scale, with perfect competition in goods and factor markets. The production

functions are specified as: $\mathrm{X}=\mathrm{F}\left(\mathrm{s}_{\mathrm{X}} \mathrm{K}, \mathrm{u}_{\mathrm{X}} \mathrm{H}\right)=\mathrm{u}_{\mathrm{X}} \mathrm{Hf}\left(\mathrm{k}_{\mathrm{X}}\right), \mathrm{Y}=\mathrm{G}\left(\mathrm{s}_{\mathrm{Y}} \mathrm{K}, \mathrm{u}_{\mathrm{Y}} \mathrm{H}\right)=\mathrm{u}_{\mathrm{Y}} \mathrm{Hg}\left(\mathrm{k}_{\mathrm{Y}}\right)$, and $\mathrm{Z}=\mathrm{J}\left(\mathrm{s}_{\mathrm{Z}} \mathrm{K}, \mathrm{u}_{\mathrm{Z}} \mathrm{H}\right)=\mathrm{u}_{\mathrm{Z}} \mathrm{Hj}\left(\mathrm{k}_{\mathrm{Z}}\right)$, where $\mathrm{s}_{\mathrm{i}}$ and $\mathrm{u}_{\mathrm{i}}$ are the shares of physical and human capital, respectively, allocated to production in sector $\mathrm{i}$ and $\mathrm{k}_{\mathrm{i}} \equiv\left(\mathrm{s}_{\mathrm{i}} \mathrm{K}\right) /\left(\mathrm{u}_{\mathrm{i}} \mathrm{H}\right)$ is the physical to human capital ratio in sector $\mathrm{i}$ for $\mathrm{i}$ $=\mathrm{X}, \mathrm{Y}, \mathrm{Z}$. The output per unit human capital functions, $\mathrm{f}, \mathrm{g}$, and $\mathrm{j}$ are assumed to be strictly increasing and strictly concave. 
The investment (education) good will provide additions to the stock of physical (human) capital and the evolution of the stocks will then be given by

$$
\begin{aligned}
& \dot{\mathrm{K}}=\mathrm{u}_{\mathrm{x}} \mathrm{Hf}\left(\mathrm{k}_{\mathrm{x}}\right)-\delta \mathrm{K} \\
& \dot{\mathrm{H}}=\mathrm{u}_{\mathrm{Y}} \mathrm{Hg}\left(\mathrm{k}_{\mathrm{Y}}\right)-\eta \mathrm{H}
\end{aligned}
$$

where $\delta(\eta)$ is the rate of depreciation of physical (human) capital. For the IWE, a closed economy, consumption (C) must be no greater than the output of the consumption good sector $(\mathrm{Z})$

$$
\mathrm{C} \leq \mathrm{u}_{\mathrm{Z}} \mathrm{Hj}\left(\mathrm{k}_{\mathrm{Z}}\right)
$$

The resource constraints require that factor demands for human and physical capital be no greater than their respective supplies and can be expressed as

$$
\sum_{i=X, Y, Z} u_{i} \leq 1, \quad \sum_{i=X, Y, Z} u_{i} k_{i} \leq k, \quad \text { with } u_{i} \in[0,1]
$$

where $\mathrm{k} \equiv \mathrm{K} / \mathrm{H}$ is the aggregate physical to human capital ratio (or, in short, the capital/labor ratio). The problem of the representative agent is specified as

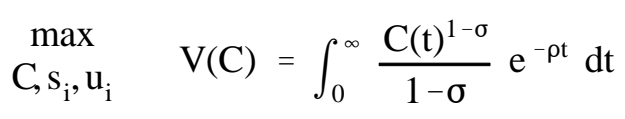

subject to (1), (2), $\mathrm{H}(0)=\mathrm{H}_{0}>0$ and $\mathrm{K}(0)=\mathrm{K}_{0}>0$.

where $\sigma \in[0, \infty)$ is the inverse of the constant intertemporal elasticity of substitution.

Since our primary concern is to characterize the BGP of the IWE in which all sectors are in operation, we concentrate on interior solutions with $0<s_{i}<1$ and $0<u_{i}<1$ for $i=X, Y, Z$. As the costate variables associated with the state variables $\mathrm{H}$ and $\mathrm{K}$ ( $\lambda$ and $\mu$ respectively) and Lagrange multiplier associated with $(1 \mathrm{c})(\gamma)$ are measured in utility units, it is convenient to express the necessary conditions to (P) by defining $\mathrm{p}_{\mathrm{X}} \equiv \mu / \gamma$ and $\mathrm{p}_{\mathrm{Y}} \equiv \lambda / \gamma$ as the relative price of the investment good and education, respectively, in terms of the numeraire consumption good. ${ }^{5}$ The associated necessary and transversality conditions are given by: ${ }^{6}$ 


$$
\begin{gathered}
\mathrm{C}^{-\sigma}-\gamma=0 \\
\mathrm{r}=\mathrm{p}_{\mathrm{X}} \mathrm{f}^{\prime}\left(\mathrm{k}_{\mathrm{X}}\right)=\mathrm{p}_{\mathrm{Y}} \mathrm{g}^{\prime}\left(\mathrm{k}_{\mathrm{Y}}\right)=\mathrm{j}^{\prime}\left(\mathrm{k}_{\mathrm{Z}}\right) \\
\mathrm{w}=\mathrm{p}_{\mathrm{X}}\left(\mathrm{f}\left(\mathrm{k}_{\mathrm{X}}\right)-\mathrm{k}_{\mathrm{X}} \mathrm{f}^{\prime}\left(\mathrm{k}_{\mathrm{X}}\right)\right)=\mathrm{p}_{\mathrm{Y}}\left(\mathrm{g}\left(\mathrm{k}_{\mathrm{Y}}\right)-\mathrm{k}_{\mathrm{Y}} \mathrm{g}^{\prime}\left(\mathrm{k}_{\mathrm{Y}}\right)\right)=\left(\mathrm{j}\left(\mathrm{k}_{\mathrm{Z}}\right)-\mathrm{k}_{\mathrm{Z}} \mathrm{j}^{\prime}\left(\mathrm{k}_{\mathrm{Z}}\right)\right) \\
\dot{\mu}=\mu(\rho+\delta)-\mu \mathrm{s}_{\mathrm{X}} \mathrm{f}^{\prime}-\lambda \mathrm{s}_{\mathrm{y}} \mathrm{g}^{\prime}-\gamma \mathrm{s}_{\mathrm{z}} \mathrm{j}^{\prime} \\
\dot{\lambda}=\lambda(\rho+\eta)-\mu \mathrm{u}_{\mathrm{x}}\left(\mathrm{f}-\mathrm{k}_{\mathrm{X}} \mathrm{f}^{\prime}\right)-\lambda \mathrm{u}_{\mathrm{y}}\left(\mathrm{g}-\mathrm{k}_{\mathrm{y}} \mathrm{g}^{\prime}\right)-\gamma \mathrm{u}_{\mathrm{z}}\left(\mathrm{j}-\mathrm{k}_{\mathrm{z}} \mathrm{j}^{\prime}\right) \\
\lim _{\mathrm{t} \rightarrow \infty} \mathrm{e}^{-\mathrm{\rho t}} \mu(\mathrm{t}) \mathrm{K}(\mathrm{t})=0, \quad \lim _{\mathrm{t} \rightarrow \infty} \mathrm{e}^{-\rho \mathrm{t}} \lambda(\mathrm{t}) \mathrm{H}(\mathrm{t})=0 .
\end{gathered}
$$

where $r$ and $w$ denote the return on a unit of physical capital and human capital, respectively, measured in units of the consumption good. Conditions (3b) and (3c) require that the marginal revenue product of the respective factors of production be equalized across sectors. (3d) and (3e) are the Euler equations governing the efficiency of capital accumulation and (3f) provides the transversality conditions.

Letting $\phi_{\mathrm{i}}(\mathrm{w}, \mathrm{r})$ denote the unit cost function for sector $\mathrm{i}$, conditions (3b) and (3c) for the equalization of returns across sectors can equivalently be expressed as requiring that price equal unit cost in each sector,

$$
\phi_{\mathrm{X}}(\mathrm{w}, \mathrm{r})=\mathrm{p}_{\mathrm{X}}, \quad \phi_{\mathrm{Y}}(\mathrm{w}, \mathrm{r})=\mathrm{p}_{\mathrm{Y}}, \quad \phi_{\mathrm{Z}}(\mathrm{w}, \mathrm{r})=1
$$

where $\left(\partial \phi_{\mathrm{i}} / \partial \mathrm{r}\right) /\left(\partial \phi_{\mathrm{i}} / \partial \mathrm{w}\right)=\mathrm{k}_{\mathrm{i}}$. Letting $v_{\mathrm{i}}$ denote the growth rate of variable $\mathrm{i}$ and using the definition of relative prices, the Euler equations, (3d) and (3e), can be combined to yield

$$
\frac{\mathrm{r}}{\mathrm{p}_{\mathrm{X}}}+v_{\mathrm{p}_{\mathrm{X}}}-\delta=\frac{\mathrm{w}}{\mathrm{p}_{\mathrm{Y}}}+v_{\mathrm{p}_{\mathrm{Y}}}-\eta
$$

This condition is referred to as the intertemporal no-arbitrage condition, because it requires equalization of the net rate of return to investment in physical capital (rental rate plus rate of capital gain less depreciation) to the net rate of return to investment in human capital.

The evolution of consumption along the optimal path is obtained by differentiating (3a) with respect to $t$ and noting that $\dot{\gamma} / \gamma=\dot{\mu} / \mu-\dot{\mathrm{p}}_{X} / \mathrm{p}_{X}$, which yields $v_{\mathrm{C}}=(1 / \sigma)\left(\mathrm{r} / \mathrm{p}_{\mathrm{X}}+v_{\mathrm{p}_{\mathrm{X}}}-\rho-\delta\right)$. Defining $\Omega(\mathrm{t})=$ $p_{X}(t) K(t)+p_{Y}(t) H(t)$ to be wealth at time $t$, it can be shown (e.g. Barro and Sala-i-Martin (1995, pp 66-7)) 
that these preferences imply a consumption function for households with a marginal propensity to consume out of wealth at each time $t$,

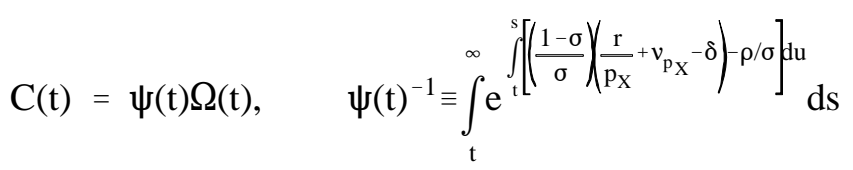

The growth rate of wealth along the optimal path will then satisfy

$$
v_{\Omega}=\left(\frac{r}{p_{X}}+v_{p_{X}}-\delta-\psi\right)
$$

along the optimal path. Note that if the economy is made up of $\mathrm{n}$ households with initial endowments $\left\{\mathrm{K}_{0}{ }^{\mathrm{i}}, \mathrm{H}_{0}{ }^{\mathrm{i}}\right\}$, the evolution of household consumption and wealth will also be governed by (6) and (7). Since household consumption is determined by the level of wealth, and not its composition, households will be indifferent between all pairs $\left\{v_{\mathrm{K}}^{\mathrm{i}}(\mathrm{t}), v_{\mathrm{H}}^{\mathrm{i}}(\mathrm{t})\right\}$ that yield the same the optimal growth rate of wealth because the intertemporal arbitrage condition equalizes returns across assets. Thus, the solution to $(\mathrm{P})$ will determine the aggregate accumulation of factors, $\dot{\mathrm{K}}(\mathrm{t})$ and $\dot{\mathrm{H}}(\mathrm{t})$, but not the values for individual households. This contrasts with the case where the stock of labor is exogenously given (or grows at an exogenously given rate). With exogenous growth of $\mathrm{H},(7)$ will uniquely determine $v_{\mathrm{K}}^{\mathrm{i}}$ as a function of household endowments and the exogenously given value of $v_{\mathrm{H}}$. The indifference over the composition of wealth accumulation where both factors are accumulated will play a significant role in the open economy case considered below.

\subsection{Existence, Uniqueness and Stability of Balanced Growth}

We now establish the conditions under which there will exist a unique, saddle path stable, balanced growth path (BGP) for the IWE satisfying (3) in which $\mathrm{C}, \mathrm{H}$, and $\mathrm{K}$ grow at a common rate. On the BGP, prices of factors and goods will be constant, as will the sectoral allocations of factors $\left(s_{i}\right.$ and $u_{i}$ for $\left.i=X, Y, Z\right)$. 
We first provide conditions under which there will exist a unique set of goods and factor prices associated with the BGP and establish the unique BGP growth rate.

If a BGP exists, then (5) must be satisfied with $v_{\mathrm{p}_{\mathrm{X}}}=v_{\mathrm{p}_{\mathrm{Y}}}=0$. With constant relative prices, (4) and (5) represent a system of four equations that can be solved for the prices (w,r, $\left.\mathrm{p}_{\mathrm{X}}, \mathrm{p}_{\mathrm{Y}}\right)$ consistent with balanced growth for the IWE. Defining $\Gamma \equiv\left\{\left(w, r, p_{X}, p_{Y}\right) \mid \phi_{i}(w, r)=p_{i}\right.$, for $\left.i=X, Y, Z\right\}$ to be the set of price vectors satisfying the competitive profit conditions, we can derive a condition for the existence of a unique price vector consistent with balanced growth.

Proposition 1: If $\underset{\left(w, r, p_{X}, p_{Y}\right) \in \Gamma}{\text { u p }} \in \frac{r}{p_{X}}-\frac{w}{p_{Y}}>\delta-\eta>\underset{\left(w, r, p_{X}, p_{Y}\right) \in \Gamma}{\inf } \frac{r}{p_{X}}-\frac{w}{p_{Y}}$, then there exists a unique vector $\left(w^{*}, r^{*}, p_{X}{ }^{*}, p_{Y}{ }^{*}\right)$ and unique sectoral factor proportions $k_{i}^{*}$ at which $v_{r}=v_{p_{X}}=v_{p_{Y}}=0$. At these prices,

$$
v_{\mathrm{C}}=v_{\Omega}=v^{*} \equiv\left(\frac{1}{\sigma}\right)\left(\frac{\mathrm{r}^{*}}{\mathrm{p}_{\mathrm{X}}{ }^{*}}-\rho-\delta\right)
$$

Proof: All proofs are provided in the appendix.

The condition of Proposition 1 is required to ensure that there exists a set of prices at which it is profitable to invest in both types of capital. The growth rate of consumption on the BGP will be proportional to the difference between the net return on capital and the rate of time preference, which is the usual result in endogenous growth models with constant intertemporal elasticity of substitution in consumption.

In order for a BGP to exist at the prices derived in Proposition 1, we must establish that there exists sectoral allocations $\mathrm{u}_{\mathrm{i}} \in(0,1)$ for $\mathrm{i}=\mathrm{X}, \mathrm{Y}, \mathrm{Z}$ and $(\mathrm{c}, \mathrm{k})>0$ which satisfy equations (1) and (2) with equality when evaluated using $v_{\mathrm{H}}=v_{\mathrm{K}}=v^{*}$ and $\mathrm{k}_{\mathrm{i}}=\mathrm{k}_{\mathrm{i}}{ }^{*}$ where $\mathrm{c}=\mathrm{C} / \mathrm{H}$. With factor prices determined by Proposition 1, this is a system of five linear equations to be solved for the balanced growth values $\left(\mathrm{c}^{*}, \mathrm{k}^{*}, \mathrm{u}_{\mathrm{X}}^{*}, \mathrm{u}_{\mathrm{Y}}^{*}, \mathrm{u}_{\mathrm{Z}}^{*}\right)$, which yields the following existence and uniqueness result. 
Proposition 2: If the maximal attainable rate of consumption growth, $v_{\max }$, satisfies $\rho>(1-\sigma) v_{\max }$ and if $\frac{r^{*}}{p_{X}\left(r^{*}\right)}-\rho-\delta>0$, then there exists a unique balanced growth equilibrium for the integrated world economy in which $H, K$, and $C$ grow at the rate $v^{*}>0$ given by (6). The aggregate physical to human capital ratio, $k^{*}$, and the consumption/wealth ratio on the BGP are given by

$$
\mathrm{k}^{*}=\frac{\mathrm{f}^{*}}{\mathrm{~g}^{*}}\left[\frac{\mathrm{k}_{\mathrm{Z}}^{*}\left(\mathrm{~g}^{*}-v^{*}-\eta\right)+\mathrm{k}_{\mathrm{Y}}^{*}\left(v^{*}+\eta\right)}{\mathrm{f}^{*}-\left(v^{*}+\delta\right) \mathrm{k}_{\mathrm{X}}^{*}+\mathrm{k}_{\mathrm{Z}}^{*}\left(v^{*}+\delta\right)}\right], \quad \frac{\mathrm{c}^{*}}{\mathrm{p}_{\mathrm{Y}}^{*}+\mathrm{p}_{\mathrm{X}}^{*} \mathrm{k}^{*}}=\frac{\mathrm{r}^{*}}{\mathrm{p}_{\mathrm{X}}^{*}}-v^{*}-\delta
$$

Finally, we note the following result which is obtained by linearizing the system around the BGP.

Proposition 3: The BGP will exhibit saddle path stability for all factor intensity rankings.

(a) If $k_{X}<k_{Y}$, then the relative price of physical to human capital, $p_{X} / p_{Y}$, will be constant along the transition path.

(b) If $k_{X}>k_{Y}, p_{X} / p_{Y}$ will be a non-increasing function of $k$ along the transition path.

This stability result extends that established in Bond, Wang and Yip (1996) in a two sector endogenous growth model in which there is a unified consumption/investment good sector and an education sector. In Part (a) where $\mathrm{k}_{\mathrm{x}}<\mathrm{k}_{\mathrm{y}}$, the quantity adjustment process is stable but the relative prices must jump immediately to the BGP value during the transition process. When $\mathrm{k}_{\mathrm{x}}>\mathrm{k}_{\mathrm{y}}(\operatorname{Part}(\mathrm{b}))$, an increase in the supply of human capital will expand the relative output of human capital which makes the quantity adjustment process unstable at fixed prices and hence the relative prices must be adjusting along the transition path. This difference between the two adjustment processes will be utilized below in the comparison of the autarky price ratios.

\section{Equilibrium in the World Economy with International Trade}

Having characterized the growth path and dynamics for the IWE, we now consider the equilibrium in the case where the world stock of factors is divided among $\mathrm{n}$ countries, with factors of production immobile 
between countries. We assume that the consumption and investment good are traded internationally, but that the education good is a non-traded service. We first derive the conditions for which the equilibrium with free trade in consumption and investment goods will be equivalent to the equilibrium of the IWE. We then provide a full characterization of the set of initial endowments consistent with the IWE for the case in which the world is on the BG:. Finally, we examine how growth in this setting can affect trade patterns by establishing the conditions under which the static and dynamic $\mathrm{H}-\mathrm{O}$ results are obtained and those conditions under which these results will fail to hold.

\subsection{Growth and Factor Price Equalization in the Open Economy}

In this section we derive the optimal consumption and investment paths for an economy facing an exogenously given world relative price for the investment good in terms of the consumption good at each

point in time, $\mathrm{p}_{\mathrm{X}}^{\mathrm{W}}(\mathrm{t})$, and a given an initial endowment $\left(\mathrm{K}_{0}^{\mathrm{i}}, \mathrm{H}_{0}^{\mathrm{i}}\right)$. We will assume that world prices are the values that were derived as part of the IWE for a given initial world factor endowment $\left(\mathrm{K}_{0}, \mathrm{H}_{0}\right)$. Our objective is to derive the conditions under which the free trade equilibrium for country i achieves the same time path of wealth and consumption as that obtained in (6) - (7) for the IWE.

Since the education good is non-traded, the accumulation of human capital in country $i$ continues to be determined by the output of sector $\mathrm{Y}$ as described in (1b). With free trade in the output of the $\mathrm{X}$ and $\mathrm{Z}$ sectors, consumption and the accumulation of physical human capital are now governed by the trade balance condition. In the absence of international lending and borrowing, the trade balance condition requires that, ${ }^{7}$

$$
c^{i}+p_{X}^{W}\left(v_{K}^{i}+\delta\right) k^{i}=u_{Z}^{i} j\left(k_{Z}^{i}\right)+p_{X}^{W} u_{X}^{i} f\left(k_{X}^{i}\right)
$$

The optimization problem for country $i$ with free trade is to maximize the objective function in $(\mathrm{P})$, subject to (10), (1b), (2) and initial factor supplies $\left(\mathrm{K}_{0}{ }^{\mathrm{i}}, \mathrm{H}_{0}^{\mathrm{i}}\right)$.

The necessary conditions for this problem are easily derived by application of the techniques used in the preceding section. The requirement that the marginal revenue products of each factor be equalized across 
all sectors that are in operation can be expressed (as in the derivation of (4)) as requiring that each sector earn nonnegative profits,

$$
\phi_{\mathrm{X}}\left(\mathrm{w}^{\mathrm{i}}, \mathrm{r}^{\mathrm{i}}\right) \geq \mathrm{p}_{\mathrm{X}}^{\mathrm{W}}, \quad \phi_{\mathrm{Y}}\left(\mathrm{w}^{\mathrm{i}}, \mathrm{r}^{\mathrm{i}}\right) \geq \mathrm{p}_{\mathrm{Y}}^{\mathrm{i}}, \quad \phi_{\mathrm{Z}}\left(\mathrm{w}^{\mathrm{i}}, \mathrm{r}^{\mathrm{i}}\right) \geq 1
$$

where $p_{Y}{ }^{i}$ is domestic price of the education good in country $i$. If country i produces both of the traded goods at time $t$, then the respective zero profit conditions in (11) must hold with strict equality. Since there is a unique solution $(\mathrm{w}, \mathrm{r})$ to these two equations for a given relative price $\mathrm{p}_{\mathrm{X}},\left(\mathrm{w}^{\mathrm{i}}(\mathrm{t}), \mathrm{r}^{\mathrm{i}}(\mathrm{t})\right)$ will be equal to the values in the IWE at time $t$ if country i produces both goods at the world price $\mathrm{p}_{\mathrm{X}}^{\mathrm{W}}(\mathrm{t})$. This is an example of the factor price equalization property of the static Heckscher-Ohlin analysis, which states that domestic factor prices are equalized across countries in the two good and two factor case if technologies are identical across countries and countries are incompletely specialized. This factor price equalization result refers to equalization of return to factors per efficiency unit of labor, which is consistent with differences in wages per worker across countries which reflect differences in efficiency units per worker. ${ }^{8}$ It should also be noted that if factor prices are equalized by trade, then the price of the non-traded good will also equal its value in the IWE, $\mathrm{p}_{\mathrm{Y}}^{\mathrm{W}}(\mathrm{t})$, if the non-traded good is produced.

It can also be shown using an argument analogous to that used in the derivation of (6) that the consumption function will be $\mathrm{C}^{\mathrm{i}}(\mathrm{t})=\psi^{\mathrm{i}}(\mathrm{t}) \Omega^{\mathrm{i}}(\mathrm{t})$, where $\Omega^{\mathrm{i}}=\mathrm{p}_{\mathrm{X}}^{\mathrm{i}} \mathrm{K}^{\mathrm{i}}+\mathrm{p}_{\mathrm{Y}}^{\mathrm{i}} \mathrm{H}^{\mathrm{i}}$ and $\psi^{\mathrm{i}}(\mathrm{t})$ is obtained by evaluating $\psi(t)$ from $(6)$ at the values $r^{i}(s) / p_{X}^{i}(s)$ and $v_{p_{X}}^{i}(s)$ for $s \geq t$. If production in country $i$ is incompletely specialized for all $\mathrm{t}$, then the conditions for factor price equalization are satisfied and the prices $\left(w^{i}(t), r^{i}(t), p_{X}^{i}(t), p_{Y}^{i}(t)\right)$ will equal the values obtained in the equilibrium of the IWE derived above. In this case, $\psi^{\mathrm{i}}(\mathrm{t})=\psi(\mathrm{t})$ and the consumption of country $\mathrm{i}$ with free trade will equal the value that would be obtained in the IWE. Along this path, the factor accumulation of country i must be such that the growth rate of wealth in country $\mathrm{i}$ is equal to the IWE value, $v_{\Omega}^{\mathrm{W}}$, determined by (7). Therefore, country $\mathrm{i}$ can achieve the same consumption level as in the IWE if there exists a path $\left\{v_{\mathrm{H}}^{\mathrm{i}}(\mathrm{t}), v_{\mathrm{K}}^{\mathrm{i}}(\mathrm{t})\right\}$ that is consistent with growth of 
wealth at rate $v_{\Omega}^{\mathrm{W}}$ and full employment, given $\left(\mathrm{w}^{\mathrm{W}}(\mathrm{t}), \mathrm{r}^{\mathrm{W}}(\mathrm{t}), \mathrm{p}_{\mathrm{X}}^{\mathrm{W}}(\mathrm{t}), \mathrm{p}_{\mathrm{Y}}^{\mathrm{W}}(\mathrm{t})\right)$.

Full employment for given world prices $\mathrm{p}_{\mathrm{X}}^{\mathrm{W}}$ requires that there exist values $\mathrm{u}_{\mathrm{i}} \in[0,1]$ such that $\sum_{\mathrm{j}=\mathrm{X}, \mathrm{Y}, \mathrm{Z}} \mathrm{u}_{\mathrm{j}} \mathrm{k}_{\mathrm{j}}{ }^{\mathrm{W}}=\mathrm{k}^{\mathrm{i}}$, where $\mathrm{k}_{\mathrm{j}}{ }^{\mathrm{W}}$ is the cost-minimizing capital/labor ratio in sector $\mathrm{j}$ at the factor price ratio $\mathrm{w}^{\mathrm{W}} / \mathrm{r}^{\mathrm{W}}$ of the IWE. Since output of the education sector is non-traded, the allocation of labor to the $\mathrm{Y}$ sector is determined from (1b) to be $\mathrm{u}_{\mathrm{Y}}^{\mathrm{i}}=\left(v_{\mathrm{H}}^{\mathrm{i}}+\eta\right) / \mathrm{g}$ W. Substituting this result in the full employment conditions yields the range of values of $\mathrm{k}^{\mathrm{i}}$ which are consistent with full employment for a given $v_{\mathrm{H}}{ }^{\mathrm{i}}(\mathrm{t})$ at BGP prices

$$
\mathrm{k}^{\mathrm{i}} \in\left[\mathrm{u}_{\mathrm{Y}}^{\mathrm{i}} \mathrm{k}_{\mathrm{Y}}^{\mathrm{W}}+\left(1-\mathrm{u}_{\mathrm{Y}}^{\mathrm{i}}\right) \min \left(\mathrm{k}_{\mathrm{X}}^{\mathrm{W}}, \mathrm{k}_{\mathrm{Z}}^{\mathrm{W}}\right), \quad \mathrm{u}_{\mathrm{Y}}^{\mathrm{i}} \mathrm{k}_{\mathrm{Y}}^{\mathrm{W}}+\left(1-\mathrm{u}_{\mathrm{Y}}^{\mathrm{i}}\right) \max \left(\mathrm{k}_{\mathrm{X}}^{\mathrm{W}}, \mathrm{k}_{\mathrm{Z}}^{\mathrm{W}}\right)\right]
$$

(12) requires that the relative factor endowment of country $i$ be no greater (less) than that required when country $i$ produces only the most (least) physical capital intensive traded good and the non-traded good in the proportions required to achieve $v_{\mathrm{H}}{ }^{\mathrm{i}}(\mathrm{t})$. In Figure 1, the set of values $v_{\mathrm{H}}{ }^{\mathrm{i}}$ and $\mathrm{k}^{\mathrm{i}}$ that satisfy (12) for a case where $\mathrm{k}_{\mathrm{X}}{ }^{\mathrm{W}}(\mathrm{t})>\mathrm{k}_{\mathrm{Y}}{ }^{\mathrm{W}}(\mathrm{t})>\mathrm{k}_{\mathrm{Z}}{ }^{\mathrm{W}}(\mathrm{t})$ are illustrated by the triangle $\mathrm{ABC}$.

To satisfy the wealth accumulation condition, $v_{\mathrm{H}}^{\mathrm{i}}(\mathrm{t})$ and $v_{\mathrm{K}}^{\mathrm{i}}(\mathrm{t})$ must be such that $v_{\Omega}^{\mathrm{i}}$ equals $v_{\Omega}^{\mathrm{W}}$ as defined in (7), which requires

$$
v_{\mathrm{H}}^{\mathrm{i}}+\left(\frac{\mathrm{p}_{\mathrm{X}}^{\mathrm{W}}}{\mathrm{p}_{\mathrm{Y}}^{\mathrm{W}}}\right) \mathrm{k}^{\mathrm{i}} v_{\mathrm{K}}^{\mathrm{i}}=\left(\frac{\mathrm{p}_{\mathrm{X}}^{\mathrm{W}}}{\mathrm{p}_{\mathrm{Y}}^{\mathrm{W}}}\right) \mathrm{k}^{\mathrm{i}}\left(v_{\Omega}^{\mathrm{W}}-v_{\mathrm{p}_{\mathrm{X}}}^{\mathrm{W}}\right)+\left(v_{\Omega}^{\mathrm{W}}-v_{\mathrm{p}_{\mathrm{Y}}}^{\mathrm{W}}\right) \quad \text { with } v_{\mathrm{H}}^{\mathrm{i}} \geq-\eta, v_{\mathrm{K}}^{\mathrm{i}} \geq-\delta
$$

From (13), the upper bound on the feasible $v_{\mathrm{H}}^{\mathrm{i}}$ occurs where $v_{\mathrm{K}}^{\mathrm{i}}=-\delta$, and occurs where $v_{\mathrm{H}}^{\mathrm{i}}=$ $\left.\mathrm{p}_{\mathrm{X}} \mathrm{k}^{\mathrm{W}}\left(v_{\Omega}^{\mathrm{W}}-v_{\mathrm{p}_{\mathrm{X}}}^{\mathrm{W}}-\delta\right) / \mathrm{p}_{\mathrm{Y}}^{\mathrm{W}}+\left(v_{\Omega}^{\mathrm{W}}-v_{\mathrm{p}_{\mathrm{Y}}}^{\mathrm{W}}\right)\right]$. This upper bound is illustrated by the line FDE in Figure 1. The values of $v_{\mathrm{H}}^{\mathrm{i}}$ and $\mathrm{k}^{\mathrm{i}}$ consistent with (13) illustrated in Figure 1 by the area between FDE and $v_{\mathrm{H}}^{\mathrm{i}}=-\eta$. It then follows that the set BCDE in Figure 1 is the set of values $v_{\mathrm{H}}(\mathrm{t})$ and $\mathrm{k}(\mathrm{t})$ that are consistent with achieving IWE consumption level defined by (6) at time t, since they satisfy both the full employment condition (12) and the wealth accumulation condition (13).

$$
\text { Let } \mathrm{B}(\mathrm{t})=\left\{v_{\mathrm{H}}, v_{\mathrm{K}}, \mathrm{k} \mid\left(v_{\mathrm{H}}, v_{\mathrm{K}}\right) \text { satisfy (12) and (13) given }\left(\mathrm{w}^{\mathrm{W}}(\mathrm{t}), \mathrm{r}^{\mathrm{W}}(\mathrm{t}), \mathrm{p}_{\mathrm{X}}^{\mathrm{W}}(\mathrm{t}), \mathrm{p}_{\mathrm{Y}}^{\mathrm{W}}(\mathrm{t})\right)\right\} \text {. Country } \mathrm{i}
$$
can attain the consumption level associated with the IWE for endowment $\mathrm{k}^{\mathrm{i}}(0)$ if there exists a time path 
$\left\{v_{\mathrm{H}}^{\mathrm{i}}(\mathrm{t}), v_{\mathrm{H}}^{\mathrm{i}}(\mathrm{t}), \mathrm{k}^{\mathrm{i}}(\mathrm{t})\right\} \in \mathrm{B}(\mathrm{t})$ for all $\mathrm{t}$. By construction, the path $\left\{v_{\mathrm{H}}{ }^{\mathrm{W}}(\mathrm{t}), v_{\mathrm{H}}{ }^{\mathrm{W}}(\mathrm{t}), \mathrm{k}^{\mathrm{W}}(\mathrm{t})\right\}$ which characterizes the optimal solution to the optimization problem $(\mathrm{P})$ for the IWE given $\mathrm{k}^{\mathrm{W}}(0)$ will satisfy this condition. The important point to note is that if there exists more than one such path from an initial $\mathrm{k}^{\mathrm{i}}(0)$, all the paths will be utility equivalent because wealth and consumption are the same at each point in time along any such path.

\subsection{Factor Price Equalization when the World is on the BGP}

Characterization of feasible paths for country $\mathrm{i}$ is complicated by the fact that the set $\mathrm{B}(\mathrm{t})$ depends on calendar time if goods prices are changing in the IWE. One way to simplify the analysis is to assume that the initial world factor supplies satisfy $\mathrm{K}_{0} / \mathrm{H}_{0}=\mathrm{k}^{*}$, so that the world is on the BGP characterized in Propositions 2 and 3 with $\mathrm{p}_{\mathrm{X}}{ }^{\mathrm{W}}(\mathrm{t})=\mathrm{p}_{\mathrm{X}}{ }^{*}$. In this section we will examine the existence of two general classes of factor accumulation paths which satisfy (12) and (13): balanced growth paths in which $v_{H}{ }^{i}(t)=v_{K}^{i}(t)=$ $v^{*}$ and $\mathrm{k}^{\mathrm{i}}(\mathrm{t})=\mathrm{k}^{\mathrm{i}}$ for all $\mathrm{t}$ and unbalanced growth paths in which $v_{\mathrm{H}}^{\mathrm{i}}(\mathrm{t}) \neq v_{\mathrm{K}}^{\mathrm{i}}(\mathrm{t}) \neq v^{*}$ and $\mathrm{k}^{\mathrm{i}}(\mathrm{t}) \neq \mathrm{k}^{\mathrm{i}}$ for some $\mathrm{t}$.

The following propositions establish the conditions under which there exist $\left\{v_{H}{ }^{i}(t), v_{K}^{i}(t), k^{i}(t)\right\}$ that are consistent with attainment of the BGP utility level in these two classes of solution for all t.

Proposition 4: Let $\mathrm{u}_{Y}^{*} \equiv\left(v^{*}+\eta\right) / g^{*}$.

(a) If the world price of good $X$ is constant at the value $p_{X}{ }^{*}$ obtained from the BGP of the integrated world economy and country $i$ has an endowment $k$ satisfying

$$
{ }^{i} \in\left[u_{Y}^{*} k_{Y}^{*}+\left(1-u_{Y}^{*}\right) \min \left(k_{X}^{*}, k_{Z}^{*}\right), \quad u_{Y}^{*} k_{Y}^{*}+\left(1-u_{Y}^{*}\right) \max \left(k_{X}^{*}, k_{Z}^{*}\right)\right]
$$

then there exists a BGP for country $i$ in which its consumption and stocks of physical and human capital all grow at the rate $v^{*}$.

(b) Choose any $k_{1}, k_{2} \in\left(u_{Y}^{*} k_{Y}^{*}+\left(1-u_{Y}^{*}\right) \min \left(k_{X}^{*}, k_{Z}^{*}\right), \quad u_{Y}^{*} k_{Y}^{*}+\left(1-u_{Y}^{*}\right) \max \left(k_{X}^{*}, k_{Z}^{*}\right)\right)$. If $k^{i}\left(t_{1}\right)=k_{l}$, then there exists a $t_{2}>t_{1}$ and a feasible path $v_{H}^{i}(t)$ such that $k^{i}\left(t_{2}\right)=k_{2}$.

Proposition 4(a) specifies the range of endowments that are consistent with a balanced growth equilibrium for a small open economy, where (14) follows immediately from evaluation of (12) at $v_{\mathrm{H}}^{\mathrm{i}}=v^{*}$. Proposition 4(b) shows that any physical/human capital ratio in the interior of the region consistent with balanced growth 
can be reached from any other point in the region in finite time through an appropriate path of human capital investment. This creates a continuum of unbalanced growth equilibria, in which $\mathrm{k}^{\mathrm{i}}$ varies over time. The balanced and unbalanced growth equilibria are utility equivalent, since consumption will be equivalent on all of these paths from the derivation of (12) and (13).

In addition to the conditions described by Proposition 4(b), there is a second way in which unbalanced growth may be consistent with the BGP utility level occurs when the initial factor supplies lie outside the range in (14). If $\mathrm{k}^{\mathrm{i}}(\mathrm{t})$ does not satisfy (14), initially for country $\mathrm{i}$, attainment of the BGP utility level through a balanced growth equilibrium is not possible. However, in such a case unbalanced growth can be consistent with factor price equalization and the attainment of the BGP utility level provided that there exists a time path for $\left\{v_{\mathrm{H}}^{\mathrm{i}}(\mathrm{t}), v_{\mathrm{K}}^{\mathrm{i}}(\mathrm{t})\right\}$ which satisfies (12), (13), and is such that $\mathrm{k}^{\mathrm{i}}$ converges to the range in (14).

For example, suppose that initially $\mathrm{k}^{\mathrm{i}}(\mathrm{t})$ is below the lower bound described in (14) and thus the economy is unable to attain the BGP utility level with balanced growth in factors as described in Proposition 4(b). For the economy to eventually enter the range consistent with (14), the time path of factor accumulation must be such that $\dot{\mathrm{k}}^{\mathrm{i}}(\mathrm{t})>0$, which requires $\mathrm{u}_{\mathrm{Y}}^{\mathrm{i}} \in\left[0, \mathrm{u}_{\mathrm{Y}}^{*}\right)$. To be consistent with factor price equalization and full employment, $\mathrm{k}^{\mathrm{i}}(\mathrm{t})$ and $\left.v_{\mathrm{H}}{ }^{\mathrm{i}} \mathrm{t}\right)$ must satisfy $(12)$ and hence $\mathrm{u}_{\mathrm{Y}}{ }^{*} \mathrm{k}_{\mathrm{Y}}{ }^{*}+\left(1-\mathrm{u}_{\mathrm{Y}}{ }^{*}\right) \min \left(\mathrm{k}_{\mathrm{X}}{ }^{*}, \mathrm{k}_{\mathrm{Z}}{ }^{*}\right)>$ $\min \left(\mathrm{k}_{\mathrm{X}}{ }^{*}, \mathrm{k}_{\mathrm{Z}}{ }^{*}\right)$ and $\mathrm{k}^{\mathrm{i}} \in\left[\min \left(\mathrm{k}_{\mathrm{X}}{ }^{*}, \mathrm{k}_{\mathrm{Z}}{ }^{*}\right), \mathrm{u}_{\mathrm{Y}}{ }^{*} \mathrm{k}_{\mathrm{Y}}{ }^{*}+\left(1-\mathrm{u}_{\mathrm{Y}}{ }^{*}\right) \min \left(\mathrm{k}_{\mathrm{X}}{ }^{*}, \mathrm{k}_{\mathrm{Z}}{ }^{*}\right)\right]$. The first restriction will only be satisfied when $\min \left(\mathrm{k}_{\mathrm{X}}{ }^{*}, \mathrm{k}_{\mathrm{Z}}{ }^{*}\right)<\mathrm{k}_{\mathrm{Y}}{ }^{*}$. Intuitively, the economy initially possesses too little physical capital relative to human capital to support a balanced growth equilibrium. When the non-traded good uses physical capital relatively intensively compared to $\min \left(\mathrm{k}_{\mathrm{X}}{ }^{*}, \mathrm{k}_{\mathrm{Z}}{ }^{*}\right)$, decreases in the production of the non-traded good increases the relative amount of physical capital available to produce traded goods by "relaxing" the full employment conditions. Suppose instead $\mathrm{k}_{\mathrm{Y}}{ }^{*}<\min \left(\mathrm{k}_{\mathrm{X}}{ }^{*}, \mathrm{k}_{\mathrm{Z}}{ }^{*}\right)$ and thus $\mathrm{Y}$ uses human capital intensively relative to $\min \left(\mathrm{k}_{\mathrm{X}}{ }^{*}, \mathrm{k}_{\mathrm{Z}}{ }^{*}\right)$. In this case, decreases in the production of the non-traded good will increase (decrease) the relative amount of the amount of human (physical) capital available to produce traded goods and the full 
employment conditions will be more restrictive. In such a case, values of $\mathrm{k}^{\mathrm{i}}<\mathrm{u}_{\mathrm{Y}}{ }^{*} \mathrm{k}_{\mathrm{Y}}{ }^{*}+\left(1-\mathrm{u}_{\mathrm{Y}}{ }^{*}\right) \min \left(\mathrm{k}_{\mathrm{X}}{ }^{*}, \mathrm{k}_{\mathrm{Z}}{ }^{*}\right)$ will not be consistent with BGP utility levels.

A similar argument can be used to show that if $\mathrm{k}_{\mathrm{Y}}{ }^{*}>\max \left(\mathrm{k}_{\mathrm{X}}{ }^{*}, \mathrm{k}_{\mathrm{Z}}{ }^{*}\right)$ full employment can be attained for a range of values of $\mathrm{k}^{\mathrm{i}}$ exceeding $\mathrm{u}_{\mathrm{Y}}{ }^{*} \mathrm{k}_{\mathrm{Y}}{ }^{*}+\left(1-\mathrm{u}_{\mathrm{Y}}{ }^{*}\right) \max \left(\mathrm{k}_{\mathrm{X}}{ }^{*}, \mathrm{k}_{\mathrm{Z}}{ }^{*}\right)$ with $\dot{\mathrm{k}}^{\mathrm{i}}(\mathrm{t})<0$. Let $v_{\mathrm{H}}^{\max } \equiv v^{*}+$ $\mathrm{p}_{\mathrm{X}}^{*} \mathrm{k}\left(\delta+v^{*}\right) / \mathrm{p}_{\mathrm{Y}}^{*}$ be the maximum growth rate for human capital consistent with (13), which is attained when $v_{\mathrm{K}}=-\delta$. The upper bound on this region occurs where the growth rate of human capital is at the maximum valued defined in (11), which yields the following result:

Proposition 5: The possibility of unbalanced growth expands the range of endowments for which the BGP utility level can be obtained in the following cases:

(a) If $\mathrm{k}^{i} \in\left[\min \left(k_{X}^{*}, k_{Z}^{*}\right), \quad u_{Y}^{*} k_{Y}^{*}+\left(1-u_{Y}^{*}\right) \min \left(k_{X}^{*}, k_{Z}^{*}\right)\right)$ and $\mathrm{k}_{Y}^{*}>\min \left(k_{X}^{*}, k_{Z}^{*}\right)$, then there exists a continuum of paths $\left\{v_{H}^{i}(t), v_{K}^{i}(t)\right\}$ satisfying (12) with $c^{i}(t)=c^{*}$ for all $t$. Along any of these paths, $\dot{k}^{i}(t)>0$ for all t for which $k^{i}(t)$ is in this interval.

If $\mathrm{k}^{i} \in\left(u_{Y}^{*} k_{Y}^{*}+\left(1-u_{y}^{*}\right) \max \left(k_{X}^{*}, k_{Z}^{*}\right), \quad u_{Y}^{\max } k_{Y}^{*}+\left(1-u_{y}^{\max }\right) \max \left(k_{X}^{*}, k_{Z}^{*}\right)\right]$ and $\mathrm{k}_{Y}^{*}>\max \left(k_{X}^{*}, k_{Z}^{*}\right)$ where $\mathrm{u}_{Y}^{\max } \equiv\left(v_{H}^{\max }+\eta\right) / g^{*}$, then there exists a continuum of paths $\left\{v_{H}^{i}(t), v_{K}^{i}(t)\right\}$ satisfying (12) with $c^{i}(t)=c^{*}$ for all $t$. Along any of these paths, $\dot{k}^{i}(t)<0$ for all $t$ for which $k^{i}(t)$ is in this interval.

Thus, a continuum of unbalanced growth equilibria emerges in a small, open economy over a nontrivial set of parameters as specified in Propositions 4(b) and 5. For initial endowments outside the union of the intervals described in Propositions 4 and 5, the BGP utility level will not be attainable.

The equilibrium of the IWE can be duplicated by free trade in $\mathrm{X}$ and $\mathrm{Z}$ if the initial endowments $\mathrm{k}_{0}{ }^{\mathrm{i}}$ lie in the range identified in Propositions 4 and 5 for all countries. Figure 2 uses a production box diagram, which is frequently used to illustrate the region of endowments consistent with factor price equalization in the static Heckscher-Ohlin model, to illustrate the above results. The dimensions of the box are the supplies of physical and human capital in the world economy at time $t$, normalized by dividing by $\mathrm{e}^{v^{*} \mathrm{t}}$, which will be constant in the equilibrium of the IWE. The diagonal of the box will have a slope of $\mathrm{k}^{*}$, the relative factor 
endowment of the world economy on the BGP. Denoting the countries as A and B respectively, any point in the box denotes an initial distribution of world endowments between the two countries, with country A's (B's) endowment measured relative to the origin $\mathrm{O}_{A}\left(\mathrm{O}_{B}\right)$. The line segments $\mathrm{O}_{A} \mathrm{C}$ and $\mathrm{O}_{\mathrm{A}} \mathrm{D}$ are drawn with slopes equal to the upper and lower bounds in (14), so that any initial endowment lying within the cone defined by these line segments is consistent with a balanced growth equilibrium for country A as defined by Proposition 4(a). Similarly, endowments contained within the cone defined by the segments $\mathrm{O}_{\mathrm{B}} \mathrm{D}$ (parallel to $\mathrm{O}_{\mathrm{A}} \mathrm{C}$ ) and $\mathrm{O}_{\mathrm{B}} \mathrm{C}$ (parallel to $\mathrm{O}_{\mathrm{A}} \mathrm{D}$ ) are consistent with balanced growth for country $\mathrm{B}$. Thus, if the initial endowments are contained in the parallelogram $\mathrm{O}_{\mathrm{A}} \mathrm{CO}_{\mathrm{B}} \mathrm{D}$, the equilibrium with international trade will yield the same utility level for each household as could be achieved on the BGP of the IWE.

Suppose that Country A has an initial endowment at point E, with $\Omega_{\mathrm{E}}$ denoting the value of wealth at point E evaluated at BGP prices. On the BGP, (13) requires that factors accumulate such that normalized wealth is constant, $\Omega_{\mathrm{E}}=\left[\mathrm{p}_{\mathrm{X}}^{*} \mathrm{~K}(\mathrm{t})+\mathrm{p}_{\mathrm{Y}}^{*}(\mathrm{t}) \mathrm{H}(\mathrm{t})\right] \mathrm{e}^{-v^{*} \mathrm{t}}$ for all $\mathrm{t}$. The $\Omega_{\mathrm{E}}$ line in Figure 2 illustrates the locus of values of factor supplies for which normalized wealth is constant. In a balanced growth equilibrium for country A, physical and human capital will grow at rate $v^{*}$ and factor supplies in A will remain at point E over time. In the unbalanced growth equilibria for country A described in Proposition 4(b), factor supplies will grow at differential rates and the factor supplies in A will move along the segment of $\Omega_{\mathrm{E}}$ contained in $\mathrm{O}_{\mathrm{A}} \mathrm{CO}_{\mathrm{B}} \mathrm{D}$. Proposition 4(b) shows that for any value of $\mathrm{k}^{\mathrm{A}}$ the interior of the parallelogram, it is always possible to follow an accumulation pattern that either raises or lowers $\mathrm{k}^{\mathrm{A}}$. Note that in order to maintain the BGP for the world as a whole, balanced (unbalanced) growth in country A, must be matched by balanced (unbalanced) growth in Country B.

Proposition 5 establishes that there are two possible cases in which an economy whose initial endowment is outside the parallelogram $\mathrm{O}_{\mathrm{A}} \mathrm{CO}_{\mathrm{B}} \mathrm{D}$ can attain the BGP utility level. If the education sector is of intermediate physical capital intensity, $\mathrm{k}_{\mathrm{Y}}{ }^{*}<\min \left(\mathrm{k}_{\mathrm{X}}{ }^{*}, \mathrm{k}_{\mathrm{Z}}{ }^{*}\right)$, then the BGP utility level can be maintained for physical/human capital ratios as low as $\min \left(\mathrm{k}_{\mathrm{X}}^{*}, \mathrm{k}_{\mathrm{Z}}^{*}\right)$ by Proposition $5(\mathrm{a})$. This ratio is represented by the 
lines with slope $\mathrm{O}_{\mathrm{A}} \mathrm{F}$ and $\mathrm{O}_{\mathrm{B}} \mathrm{G}$ in Figure 1. In this case, the region of initial endowments consistent with factor price equalization for the world economy is given by the parallelogram $\mathrm{O}_{\mathrm{A}} \mathrm{GO}_{\mathrm{B}} \mathrm{F}$. If the initial endowment point is at $\mathrm{H}$, the growth rate of human capital in A must be less than $v^{*}$ along any equilibrium path and $\mathrm{k}^{\mathrm{A}}(\mathrm{t})$ must be rising along the $\Omega_{\mathrm{E}}$ line until it enters $\mathrm{O}_{\mathrm{A}} \mathrm{CO}_{\mathrm{B}} \mathrm{D}$. Finally, if the education sector is the most physical capital intensive sector, $\mathrm{k}_{\mathrm{Y}}{ }^{*}>\max \left(\mathrm{k}_{\mathrm{X}}{ }^{*}, \mathrm{k}_{\mathrm{Z}}{ }^{*}\right)$, the region consistent with the BGP of the IWE through trade will be expanded to include a region above $\mathrm{O}_{\mathrm{A}} \mathrm{F}$ and a region below $\mathrm{O}_{\mathrm{B}} \mathrm{F}$ as indicated by Proposition 5(b). For endowments in these areas, $\mathrm{k}^{\mathrm{A}}(\mathrm{t})$ must be rising towards the balanced growth region $\mathrm{O}_{\mathrm{A}} \mathrm{CO}_{\mathrm{B}} \mathrm{D}$. Finally, if the production of human capital is the most human capital intensive activity (i.e., $\left.\mathrm{k}_{\mathrm{Y}}^{*}<\min \left(\mathrm{k}_{\mathrm{X}}^{*}, \mathrm{k}_{\mathrm{Z}}^{*}\right)\right)$, then the endowments in $\mathrm{O}_{\mathrm{A}} \mathrm{CO}_{\mathrm{B}} \mathrm{D}$ are the only ones consistent with the BGP for the IWE.

\subsection{Factor Supplies and Trade Pattern}

The above discussion has focused on characterizing the paths of factor accumulation that are consistent with open economies attaining the BGP utility level. We now consider the pattern of trade along such paths and examine the validity of the static and dynamic versions of the $\mathrm{H}-\mathrm{O}$ theorem in this model.

Assuming that free trade equilibrium duplicates the IWE, imports of the consumption good per unit of human capital in country $i$ are given by $\mathrm{m}_{\mathrm{Z}}^{\mathrm{i}}=\psi\left(\mathrm{p}_{\mathrm{X}}^{\mathrm{W}_{\mathrm{k}}}{ }^{\mathrm{i}}+\mathrm{p}_{\mathrm{Y}}^{\mathrm{W}}\right)-\mathrm{u}_{\mathrm{Z}}^{\mathrm{i}} \mathrm{j}\left(\mathrm{k}_{\mathrm{Z}}^{\mathrm{W}}\right)$. The market clearing condition for the world economy requires that world consumption equal world output of $Z$, which from (1c) and (6) yields $\psi=\mathrm{u}_{\mathrm{Z}} \mathrm{W}^{\mathrm{W}} \mathrm{j}\left(\mathrm{k}_{\mathrm{Z}}{ }^{\mathrm{W}}\right) /\left(\mathrm{p}_{\mathrm{X}}{ }^{\mathrm{W}} \mathrm{k}^{\mathrm{W}}+\mathrm{p}_{\mathrm{Y}}{ }^{\mathrm{W}}\right)$, where $\mathrm{u}_{\mathrm{Z}}^{\mathrm{W}}$ is the share of world human capital allocated to Z. Substituting this result into $\mathrm{m}_{\mathrm{Z}}{ }^{\mathrm{i}}$ and using the full employment condition, we obtain

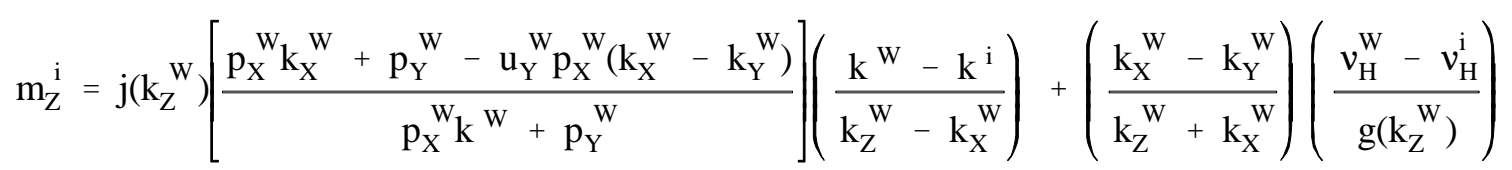

It should be noted that the characterization of the trade pattern in (15) only requires that the free trade equilibrium duplicate the IWE, and not that the world is on the BGP. If human capital is growing at the 
same rate in country $i$ as in the world economy, then the pattern of trade will be determined completely by the first term in (15). The term in brackets must be positive since $\mathrm{u}_{\mathrm{Y}}{ }^{\mathrm{W}}<1$. If the consumption good is physical (human) capital intensive relative to the investment good, then the first term will be postive iff country $i$ is human (physical) capital abundant relative to the rest of the world. This establishes that a sufficient condition for the static Heckscher-Ohlin theorem to hold is that the growth rate of human capital in country $\mathrm{i}$ equal that of the world economy. One case in which this would hold is if the world is on the BGP and country $\mathrm{i}$ is also experiencing balanced growth, so that $v_{\mathrm{H}}^{\mathrm{i}}=v_{\mathrm{H}}^{\mathrm{W}}=v^{*}$.

The second term in (15) captures the effect of variations in the growth rate of human capital on the pattern of trade when $\mathrm{k}_{\mathrm{X}}{ }^{*} \neq \mathrm{k}_{\mathrm{Y}}{ }^{*}$. Suppose that $\mathrm{Z}$ is the physical capital intensive good and country $\mathrm{i}$ is physical capital abundant relative to the world economy, so that the first term in (13) is negative. The static $\mathrm{H}-\mathrm{O}$ theorem could be violated if the second term is positive and sufficiently large. The second term will be positive if $\left.v_{\mathrm{H}}{ }^{\mathrm{i}} \mathrm{t}\right)>v_{\mathrm{H}}{ }^{\mathrm{W}}$ and $\mathrm{k}_{\mathrm{Y}}{ }^{\mathrm{W}}>\mathrm{k}_{\mathrm{X}}{ }^{\mathrm{W}}$ or if $v_{\mathrm{H}}{ }^{\mathrm{i}}(\mathrm{t})<v_{\mathrm{H}}{ }^{\mathrm{W}}$ and $\mathrm{k}_{\mathrm{Y}}{ }^{\mathrm{W}}<\mathrm{k}_{\mathrm{X}}{ }^{\mathrm{W}}$. In the case where the world is on the BGP, it can be shown that for endowments sufficiently close to ${ }^{*}$, it is always possible to find feasible values of $v_{\mathrm{H}}$ such that the pattern of trade violates that predicted on the basis of factor abundance. The failure of the $\mathrm{H}-\mathrm{O}$ theorem occurs because variations in the rate of human capital growth alter the relative supply of physical capital available to produce traded goods, because the education good must be produced locally. In the former case were $v_{\mathrm{H}}{ }^{\mathrm{i}}(\mathrm{t})>v_{\mathrm{H}}{ }^{\mathrm{W}}$ and $\mathrm{k}_{\mathrm{Y}}{ }^{\mathrm{W}}>\mathrm{k}_{\mathrm{X}}{ }^{\mathrm{W}}$, a relatively large amount of physical capital is being withdrawn from the traded goods sector to produce the physical capital intensive non-traded good and meet the high growth rate human capital. In the latter case, a relatively large amount of human capital is being released to the production of traded goods because of the relatively low output of the human capital intensive non-traded good due to the relatively low growth rate of human capital. The source of the failure of the static H-O theorem is that although country i's physical capital abundant relative to the world as a whole in terms of its gross factor endowment, the net endowment available for the production of traded goods is human capital abundant relative to the world as a whole. Thus, with unbalanced growth, the difference in 
rates of human capital accumulation across countries may cause the ranking of countries on the basis of "net of human capital accumulation" factor abundance to differ from the ranking on the basis of "gross" factor abundance. It is the former abundance that determines the pattern of trade. Intuitively, the effect of allowing the rate of accumulation of human capital to differ across countries is similar to introducing cross-country differences in the taste for non-traded goods, which can cause the H-O theorem to fail.

The above results are summarized in the following:

\section{Proposition 6:}

(a) Suppose the world is on the BGP of the IWE. If $k^{i}(t)$ is contained in the range consistent with balanced growth in (14), the static Heckscher-Ohlin theorem will hold if $v_{H}(t)=v^{*}$. However, if

${ }_{X}^{*} \neq k_{Z}^{*} \neq k_{Y}^{*}$ it is possible to find values of $k^{i}(t)$ in the neighborhood of $k^{*}$ for which there exist feasible values of $v_{H}(t) \neq v^{*}$ such that the static Heckscher-Ohlin theorem is violated at time $t$.

(b) If $v_{H}(t)=v_{H}{ }^{W}(t)$, the static Heckscher-Ohlin theorem will hold at time $t$.

Proposition 6 can also be combined with the earlier results on feasible paths for the open economy to examine the relationship between a country's initial endowments and its long run trade pattern. If an economy experiences balanced growth for all $t$, then a country's relative factor abundance will remain constant and its trade pattern will reflect the static $\mathrm{H}-\mathrm{O}$ theorem for all $\mathrm{t}$. This case is consistent with the dynamic $\mathrm{H}-\mathrm{O}$ theorem as stated in the introduction. Note however that there are unbalanced growth paths defined in Proposition 4(b) along which a country can switch from being physical capital abundant to being human capital abundant, so there can be no long run relationship between trade pattern and initial factor endowments.

Proposition 7: For any endowment ratio satisfying (14), it is possible to find an unbalanced growth path such that the dynamic $\mathrm{H}-\mathrm{O}$ theorem is violated.

The failure of these versions of the $\mathrm{H}-\mathrm{O}$ theorem results from the combination of the intertemporal no-arbitrage condition combined with factor price equalization which will occur when open economies are 
incompletely specialized in production. When the economy is incompletely specialized, the returns to factors in the open economy will be determined on world markets through factor price equalization independently of domestic factor supplies. Open economies can alter their production patterns and raise the rate of physical relative to human capital accumulation and alter altering their relative factor endowment without altering the relative return to human capital, as would occur in closed economy models. This results from the fact that the open economy can absorb the increase in supply of physical capital by increasing its exports of goods that use physical capital more intensively. Furthermore, the open economy is indifferent among these various relative factor endowments as factor prices are such that the intertemporal no-arbitrage, which must hold in the world economy, is satisfied and the returns to the two factors are equalized. These two elements, intertemporal no-arbitrage and factor price equalization, lead to a multiplicity of unbalanced growth paths for capital accumulation and a lack of convergence in relative factor supplies across countries. When there is unbalanced growth, violations of the static $\mathrm{H}-\mathrm{O}$ theorem arise as there exist paths for which a physical capital abundant country at time $\mathrm{t}$ may import the physical capital intensive good at time $\mathrm{t}$ for some factor proportions. The dynamic $\mathrm{H}-\mathrm{O}$ theorem is violated as there may exist an unbalanced growth path along which an initially physical capital abundant country can become human capital abundant.

\subsection{Factor Accumulation and Transition to the BGP}

The analysis of section 3.2 established the indeterminacy of the pattern of factor accumulation when the world is on the BGP. It is important to note that the assumption that the world is on the BGP is not critical to that result. If the path $\left\{v_{\mathrm{H}}{ }^{\mathrm{W}}(\mathrm{t}), v_{\mathrm{H}}{ }^{\mathrm{W}}(\mathrm{t}), \mathrm{k}^{\mathrm{W}}(\mathrm{t})\right\}$ of the IWE is in the interior of the set of feasible paths $\mathrm{B}(\mathrm{t})$ for all $\mathrm{t}$, then it will be possible to construct a continuum of paths in the neighborhood of the equilibrium of the IWE that will duplicate the equilibrium of the IWE.

\section{Gains from Trade and the Price Version of the Heckscher-Ohlin Theorem}

In this section we investigate the conditions under which the country with the higher physical/human capital ratio prior to trade will have a lower autarky price for the physical capital intensive traded good. We 
consider two countries, $\mathrm{A}$ and $\mathrm{B}$, with $\mathrm{k}^{\mathrm{A}}>\mathrm{k}^{\mathrm{B}}$. The autarky equilibrium in countries $\mathrm{A}$ and $\mathrm{B}$ will be given by the closed economy version of the model characterized in Section 2. We can compare the autarky prices of the countries by comparing the prices of goods on the transition path associated with the respective country's physical/human capital ratio.

First consider the case $\mathrm{k}_{\mathrm{X}}>\mathrm{k}_{\mathrm{Y}}$. The price ratio $\mathrm{p}_{\mathrm{X}} / \mathrm{p}_{\mathrm{Y}}$ is a decreasing function of $\mathrm{k}$ along the transition path in this case from Proposition 3(b). Assuming that the endowments of the countries are such that both countries are incompletely specialized in autarky, we must have $\left(\mathrm{p}_{\mathrm{X}} / \mathrm{p}_{\mathrm{Y}}\right)^{\mathrm{A}}<\left(\mathrm{p}_{\mathrm{X}} / \mathrm{p}_{\mathrm{Y}}\right)^{\mathrm{B}}$. This confirms the intuition that the relative value of a unit of physical capital must be lower in the physical capital abundant country in autarky. In addition, the Stolper-Samuelson theorem of international trade theory will apply. Thus, a reduction in the relative price of the capital intensive good (when X and Y are both being produced using human and physical capital) will result in a decline in the return to capital (see appendix for proof). That is, $\left(\mathrm{p}_{\mathrm{X}} / \mathrm{p}_{\mathrm{Y}}\right)^{\mathrm{A}}<\left(\mathrm{p}_{\mathrm{X}} / \mathrm{p}_{\mathrm{Y}}\right)^{\mathrm{B}}$ implies $\mathrm{r}^{\mathrm{A}}<\mathrm{r}^{\mathrm{B}}$ when $\mathrm{k}_{\mathrm{X}}>\mathrm{k}_{\mathrm{Y}}$. Finally, examination of the competitive profit conditions demonstrates that if both of the traded goods $\mathrm{X}$ and $\mathrm{Z}$ are being produced in each country, $\mathrm{r}^{\mathrm{A}}<\mathrm{r}^{\mathrm{B}}$ implies that $\mathrm{p}_{\mathrm{X}}^{\mathrm{A}}<\mathrm{p}_{\mathrm{X}}^{\mathrm{B}}\left(\mathrm{p}_{\mathrm{X}}^{\mathrm{A}}>\mathrm{p}_{\mathrm{X}}^{\mathrm{B}}\right)$ if $\mathrm{k}_{\mathrm{X}}>\mathrm{k}_{\mathrm{Z}}\left(\mathrm{k}_{\mathrm{X}}>\mathrm{k}_{\mathrm{Z}}\right)$ on $\left[\mathrm{r}^{\mathrm{A}}, \mathrm{r}^{\mathrm{B}}\right]$. This establishes that the price of the physical capital intensive traded good will be higher in autarky in the physical capital abundant country, conforming (b) of the static H-O theorem. ${ }^{7}$

Next consider the case with $\mathrm{k}_{\mathrm{Y}}>\mathrm{k}_{\mathrm{X}}$. Proposition 3(a) establishes that for all endowments such that open economies are diversified in production at BGP prices, the autarky price will jump immediately to the BGP value. This implies that if $\mathrm{k}^{\mathrm{A}}$ and $\mathrm{k}^{\mathrm{B}}$ lie within the region consistent with incomplete specialization in autarky, there will be no differences in autarky prices across countries and there will be no gains from trade because national consumption levels are at their BGP values in autarky. The range of initial factor supplies consistent with incomplete specialization is obtained by utilizing the full employment conditions, (2), subject to the requirement that output of the consumption good sector per unit of human capital be consistent with attainment of the BGP utility level defined by $(7 b)$ which requires $\mathrm{u}_{\mathrm{i}}^{\mathrm{Z}}\left(\mathrm{v}^{*},{ }^{\mathrm{ki}}\right)=\mathrm{c} * \mathrm{j}^{*}$. This yields a feasible 
range initial relative factor supplies of

$$
\mathrm{k}^{\mathrm{i}} \in\left[\mathrm{u}_{\mathrm{Z}}^{\mathrm{i}}\left(\mathrm{k}^{\mathrm{i}}, v^{*}\right) \mathrm{k}_{\mathrm{Z}}^{*}+\left(1-\mathrm{u}_{\mathrm{Z}}^{\mathrm{i}}\left(\mathrm{k}^{\mathrm{i}}, v^{*}\right)\right) \mathrm{k}_{\mathrm{X}}^{*}, \mathrm{u}_{\mathrm{Z}}^{\mathrm{i}}\left(\mathrm{k}^{\mathrm{i}}, v^{*}\right) \mathrm{k}_{\mathrm{Z}}^{*}+\left(1-\mathrm{u}_{\mathrm{Z}}^{\mathrm{i}}\left(\mathrm{k}^{\mathrm{i}}, v^{*}\right)\right) \mathrm{k}_{\mathrm{Y}}^{*}\right]
$$

Part (b) of the static H-O theorem will not hold in this region, as local factor endowments have no impact on prices and there will be no gains from trade.

It should be noted that the range of factor endowments in (16) is a subset of the range that is consistent with attaining the BGP utility function as derived in Propositions 4 and 5. The lower bound in (16) will be strictly greater than the lower bound consistent with the BGP utility level in Proposition 5(a) for the case $\mathrm{k}_{\mathrm{Y}}{ }^{*}>\mathrm{k}_{\mathrm{X}}{ }^{*}$. The upper bound in (16) will equal (exceed) the upper bound in Proposition 5(b) when $\mathrm{k}_{\mathrm{Z}}{ }^{*}>(<) \mathrm{k}_{\mathrm{X}}{ }^{*}$. This means that the opening of trade will expand the range of initial endowments for which the BGP utility level is attainable in the case.

\section{Proposition 8:}

(a) When the investment goods sector is physical capital intensive relative to the education sector, part (b) of the static Heckscher-Ohlin theorem holds. Gains from trade will exist for all $k^{i} \neq k^{*}$ in this case.

(b) When the investment goods sector is human capital intensive relative to the education sector, part (b) of the Heckscher-Ohlin theorem is absent and there are no gains from trade for countries whose endowments lie in the range given by (16). Trade will expand the range of endowments consistent with the BGP utility level.

\section{Concluding Remarks}

In this paper, we have considered a dynamic $\mathrm{H}-\mathrm{O}$ model in which both human and physical capital endogenously accumulate. We have shown that when the conditions for factor price equalization are met in an open economy with human and physical capital accumulation, the composition of factor accumulation will 
be indeterminate. This indeterminacy results from the fact that an economy that if an economy were to switch its investment toward human capital, it could adjust its output to produce more human capital intensive goods and increase its net exports of human capital intensive goods. Factor price equalization ensures that this change in composition of output does not lead to diminishing returns to human capital accumulation for the open economy, and the intertemporal arbitrage condition ensures that the two paths are utility equivalent. This indeterminacy results in the potential failure of the dynamic $\mathrm{H}-\mathrm{O}$ theorem, since a change in the composition of factor accumulation can lead to an eventual reversal of an economy's factor abundance relative to the rest of the world.

Several extensions are suggested by our results. The $\mathrm{H}-\mathrm{O}$ theorem is one of the most prominent in international trade and there is strong evidence that factor endowments do indeed matter in determining trade patterns. In light of the general indeterminacy in long run and short run trading patterns in this framework, it is of great interest to ask what additional features are required in this model in order to generate determinant long run comparative advantage. In related work, Trask (1998) addresses this issue and illustrates that in a model of higher dimension, in particular a model which adds a third, fixed factor of production, although there remains no tendency for relative factor endowments to converge across countries, determinant long run comparative advantage based on initial endowments will emerge.

A second extension is to consider the effects of imposing additional structure on the household decision-making process by modeling explicitly the household decision of bequests of human and physical capital. This would raise the possibility that households have preferences over the composition of their wealth and could possibly lead to convergence in relative factor endowments in a two country model. Following Findlay and Kierzkowski (1983), one way to capture these effects is to differentiate between skilled and unskilled labor and endogenize the choice of whether to become skilled (and forgo income during the learning period) or to remain unskilled. The skilled/unskilled labor differential is determined by the condition that workers be indifferent as to whether to undergo training. Stokey (1996) considers a similar 
framework for the accumulation of human capital as unskilled workers are transformed into skilled workers. While Findlay and Kierzkowski (1983) differentiate the accumulation of human capital from physical capital by considering an environment in which education requires time impacting the decisions of finitely lived agents. Stokey (1996) by contrast, incorporates time required for education by specifying a costly adjustment process for the accumulation of skilled labor. Her model is characterized by only one traded good and the international mobility of factors. Thus, all countries will converge to identical relative factor endowments as factors rather than goods are mobile. Finally, we could reexamine these issues for the case with positive human capital spillovers in production of traded goods. The presence of positive externalities may differentiate roles of human from physical capital and establish different dynamic properties. 


\section{References}

R.J. Barro, "Economic Growth in a Cross-Section of Countries," Quarterly Journal of Economics 106 (1991), 407-443.

R. J. Barro and X. Sala-i-Martin, Economic Growth, McGraw-Hill, Inc., New York, NY, 1995.

M. Baxter, "Fiscal Policy, Specialization and Trade in the Two-Sector Model: The Return of Ricardo," Journal Political Economy 100 (1992): 713-744

E. W. Bond and K. Trask, "Trade and Growth with Endogenous Human and Physical Capital Accumulation: The Case of a Small Open Economy," in Dynamics, Economic Growth, and International Trade, B.S. Jensen and K. Wong (eds.), University of Michigan Press, Ann Arbor, MI, 1997.

E. W. Bond, P. Wang, and C. Yip, “A General Two-Sector Model of Endogenous Growth with Human and Physical Capital: Balanced Growth and Transitional Dynamics," Journal of Economic Theory 68 (1996), 149-73.

J. Caballé and M. S. Santos, “On Endogenous Growth with Physical and Human Capital,” Journal of Political Economy 110 (1993), 1042-1067.

A. Deardorff and J. Hansen, "Accumulation and a Long Run Heckscher-Ohlin Theorem," Economic Inquiry 16 (1978), 288-92.

R. Findlay, "Factor Proportions and Comparative Advantage in the Long Run," Journal of Political Economy 78 (1970), 27-34.

R. Findlay, Factor Proportions, Trade, and Growth, MIT Press, Cambridge, MA, 1995.

R. Findlay and H. Kierzkowski, "International Trade and Human Capital: A Simple General Equilibrium Model,” Journal of Political Economy 91 (1983), 173-91.

O. Galor and S. Lin, "Dynamic Foundations for the Factor Endowment Model of International Trade," in Dynamics, Economic Growth, and International Trade, B.S. Jensen and K. Wong (eds.), University of Michigan Press, Ann Arbor, MI, 1997.

G. Grossman and E. Helpman, Innovation and Growth in the Global Economy, MIT Press, Cambridge MA, 1991.

L. E. Jones and R. Manuelli, "A Convex Model of Equilibrium Growth: Theory and Policy Implications," Journal of Political Economy 98 (1990), 1008-1038.

E. E. Leamer, Sources of International Comparative Advantage: Theory and Evidence, MIT Press, Cambridge MA, 1984.

R. E. Lucas, Jr., "On the Mechanics of Economic Development," Journal Monetary Economics 22 (1988), $3-42$. 
R.E. Lucas, Jr., "Making a Miracle,” Econometrica 61 (1993), 251-272.

S. Rebelo, "Long-run Policy Analysis and Long-run Growth," Journal of Political Economy 99 (1991), 500-521.

P. Romer, "Human Capital and Growth: Theory and Evidence," Carnegie Rochester Conference Series on Public Policy, 32, 1990.

P. Romer, "Increasing Returns and Long-Run Growth," Journal of Political Economy 94 (1986), 10021037.

A. Smith, "Capital Theory and Trade," in Handbook of International Economics, R. W. Jones and P. B. Kenen (eds.), North Holland, Amsterdam, 1984.

J. E. Stiglitz, "Factor Price Equalization in a Dynamic Economy," Journal of Political Economy, 78 (1970), 456-488.

N. Stokey, "Free Trade, Factor Returns, and Factor Accumulation," Journal of Economic Growth 1 (1996), 421-447.

N. Stokey, "Human Capital, Product Quality, and Growth," Quarterly Journal of Economics 106 (1991), 587-616.

N. Stokey and S. Rebelo, "Growth Effects of Flat-Rate Taxes," Journal of Political Economy 103 (1995), 519-550.

E. W. Tallman and P. Wang, "Human Capital and Endogenous Growth: Evidence from Taiwan," Journal of Monetary Economics 34 (1994), 101-124.

K. Trask, Essays on Trade and Endogenous Factor Accumulation, Ph.D. Dissertation, Pennsylvania State University, 1998.

D. Trefler, "International Factor Price Difference: Leontief Was Right!," Journal of Political Economy 101 (1993), 961-987.

H. Uzawa, "On a Two-sector Model of Economic Growth, I," Review Economic Studies 14 (1961), $407-$ 440.

J. Ventura, "Growth and Interdependence," Quarterly Journal of Economics 112 (1997), 57-84.

A. Young, "The Tyranny of Numbers: Confronting the Statistical Realities of the East Asian Experience," Quarterly Journal of Economics 110 (1995), 641-680. 


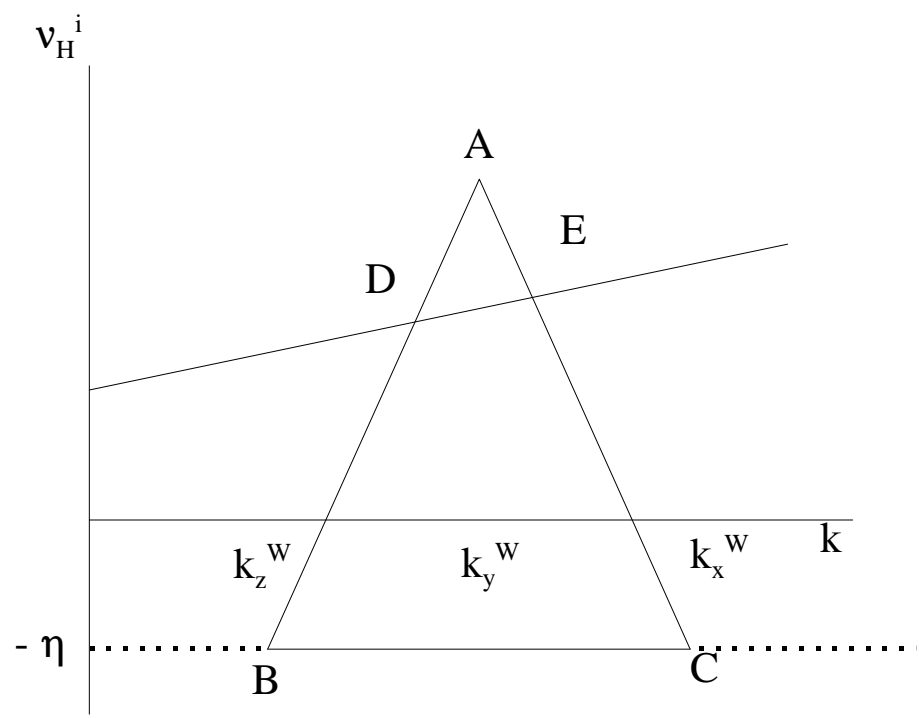

Figure 1 Set of Growth Paths Consistent with IWE at t, BCDE 


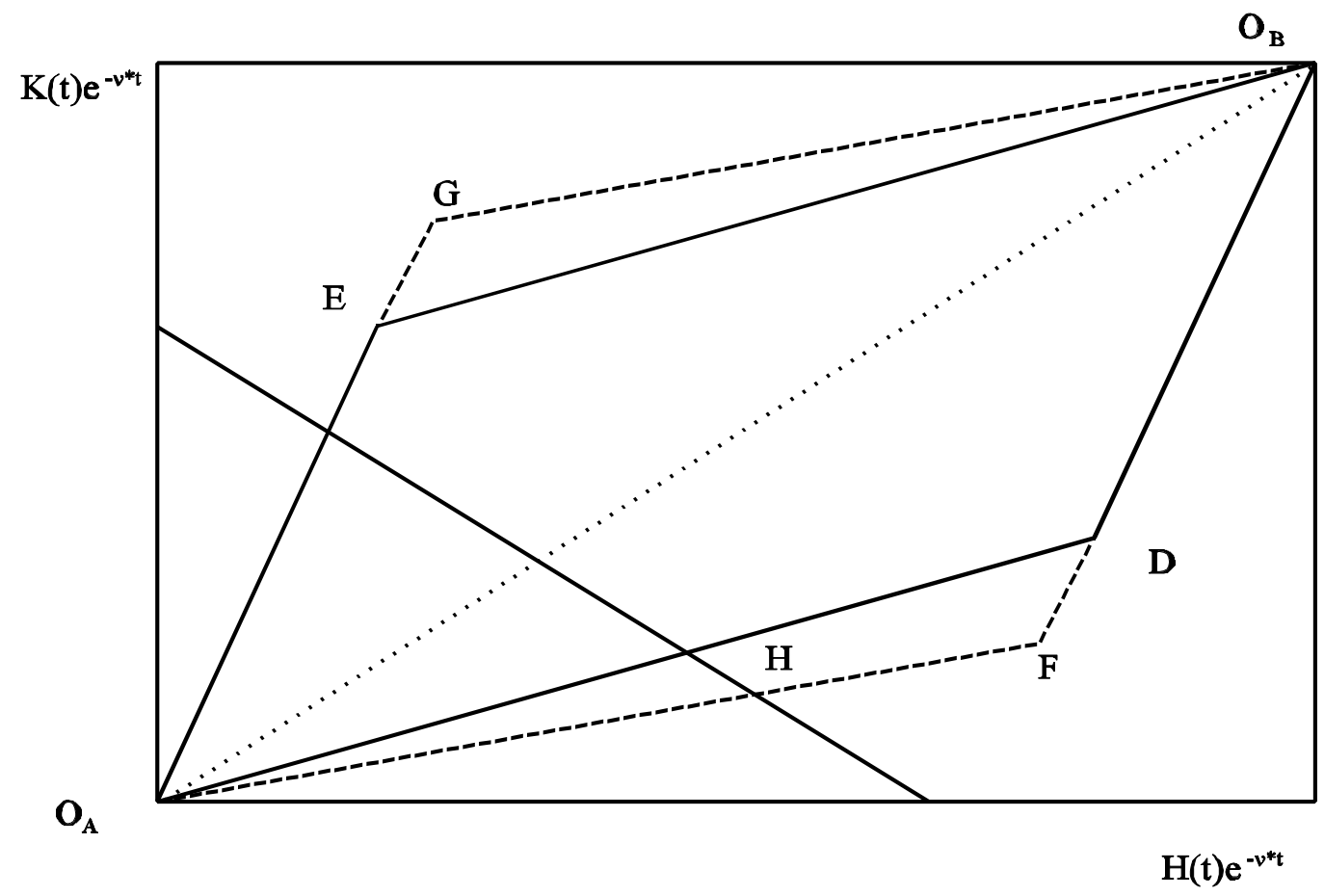

Figure 2 Region of Factor Price Equalization at BGP Prices: $\mathrm{k}_{\mathrm{X}}{ }^{*}>\mathrm{k}_{\mathrm{Y}}{ }^{*}>\mathrm{k}_{\mathrm{Z}}{ }^{*}$ : $0_{\mathrm{A}} \mathrm{D} 0_{\mathrm{B}} \mathrm{E}$ with Balanced Growth, $0_{\mathrm{A}} \mathrm{FO}_{\mathrm{B}} \mathrm{G}$ with Unbalanced Growth 


\section{Appendix}

Proof of Proposition 1: The competitive profit conditions for each sector i $=\mathrm{X}, \mathrm{Y}, \mathrm{Z}$ are:

$$
\mathrm{p}_{\mathrm{X}} \mathrm{f}=\mathrm{w}+\mathrm{rk}_{\mathrm{X}}, \quad \mathrm{p}_{\mathrm{Y}} \mathrm{g}=\mathrm{w}+\mathrm{rk}_{\mathrm{Y}}, \quad \mathrm{j}=\mathrm{w}+\mathrm{rk}_{\mathrm{Z}}
$$

With (3b), the competitive profit condition for the $\mathrm{Z}$ sector can be inverted to yield $w=\omega(\mathrm{r})$. With the interval $\mathrm{A} \in \mathbb{R}^{1}$ denoting the domain of $\omega, \omega$ is continuous with

$$
\omega^{\prime}(r)=-k_{Z}<0
$$

and can be used to solve for the prices consistent with operation of all sectors as a function of the rental rate, $\mathrm{p}_{\mathrm{i}}(\mathrm{r})=\phi_{\mathrm{i}}(\omega(\mathrm{r}), \mathrm{r})$ for $\mathrm{i}=\mathrm{X}, \mathrm{Y}$. This function $\mathrm{p}_{\mathrm{i}}(\mathrm{r})$ will be continuous on $\mathrm{A}$, where differentiation of (3b) together with (A2) gives

$$
\mathrm{dp}_{\mathrm{X}} / \mathrm{dr}=\left(\mathrm{k}_{\mathrm{X}}-\mathrm{k}_{\mathrm{Z}}\right) / \mathrm{f}, \quad \mathrm{dp}_{\mathrm{Y}} / \mathrm{dr}=\left(\mathrm{k}_{\mathrm{X}}-\mathrm{k}_{\mathrm{Z}}\right) / \mathrm{g} .
$$

Define the function

$$
\xi(r)=\frac{r}{p_{X}(r)}-\frac{\omega(r)}{p_{Y}(r)}+\eta-\delta=0
$$

which is continuous on A by construction. Combining (A2) and (A3) yields

$$
\mathrm{d}\left(\mathrm{r} / \mathrm{p}_{\mathrm{X}}(\mathrm{r})\right) / \mathrm{dr}=\mathrm{j} /\left(\mathrm{p}_{\mathrm{X}}{ }^{2} \mathrm{f}\right)>0, \mathrm{~d}\left(\omega(\mathrm{r}) / \mathrm{p}_{\mathrm{Y}}(\mathrm{r})\right) / \mathrm{dr}=-\mathrm{j} \mathrm{k}_{\mathrm{Y}} /\left(\mathrm{p}_{\mathrm{Y}}{ }^{2} \mathrm{~g}\right)<0
$$

which implies $\xi^{\prime}(\mathrm{r})>0$. The condition of the proposition ensures that there exist $\mathrm{r}$ sufficiently small that $\xi(\mathrm{r})$ $<0$ and $\mathrm{r}$ sufficiently large that $\xi(\mathrm{r})>0$, so there will be a unique value $\mathrm{r}^{*}$ such that $\xi\left(\mathrm{r}^{*}\right)=0$. The growth rate of consumption on the BGP is obtained from (6) with $v_{\mathrm{p}_{\mathrm{X}}}=0$.

Proof of Proposition 2: The existence of an $\mathrm{r}^{*}$ consistent with $v^{*}>0$ is ensured by Proposition 1 and the condition $\mathrm{r}^{*} / \mathrm{p}_{\mathrm{X}}^{*}>\delta+\rho$. From (1a) and (1b), we have

$$
\mathrm{u}_{\mathrm{X}} \mathrm{f}^{*}=\left(v^{*}+\delta\right) \mathrm{k}, \quad \mathrm{u}_{\mathrm{Y}} \mathrm{g}^{*}=v^{*}+\eta
$$

In order to have a feasible solution for the BGP, (2) must have a solution with $0<u_{i}<1$ for $i=X, Y, Z$. $u_{Y}$ $>0$ is ensured by (1b) with $v^{*}>0 . \mathrm{u}_{\mathrm{X}}>0$ follows from (1a) if (2) has a solution with $\mathrm{k}>0$. Substituting (A6) and (1c) with equality into (2) (with equalities), we can obtain the first equation of (9). A sufficient condition for $\mathrm{k}^{*}>0$ will be $\mathrm{g}^{*}-v^{*}-\eta>0$ and $\mathrm{f}^{*}-\left(v^{*}+\delta\right) \mathrm{k}_{\mathrm{x}}^{*}>0$. Since from $(\mathrm{A} 1) \mathrm{f}^{*}>\left(\mathrm{r}^{*} \mathrm{k}_{\mathrm{x}}^{*}\right) / \mathrm{p}_{\mathrm{x}}^{*}$, the latter condition will be satisfied if $\left(\mathrm{r}^{*} / \mathrm{p}_{\mathrm{X}}^{*}\right)>v^{*}+\delta$. Utilizing (8), this can be rewritten as $\left(\mathrm{r}^{*} / \mathrm{p}_{\mathrm{X}}^{*}\right)-\delta=\rho+\sigma v^{*}>v^{*}$. This inequality is obviously satisfied for $\sigma>1$. For $\sigma<1$, the assumed 
upper bound on the consumption growth rate can be used to rewrite the left hand side of the inequality $\left(\mathrm{r}^{*} / \mathrm{p}_{\mathrm{X}}^{*}\right)-\delta>(1-\sigma) v_{\max }+\sigma v^{*}$ which must exceed $v^{*}$. A similar argument can be used to show that $\mathrm{g}^{*}-v^{*}-\eta>0$, using $\mathrm{g}^{*}>\mathrm{w}^{*} / \mathrm{p}_{\mathrm{Y}}^{*}$ and (8). Therefore, there will exist a unique $\mathrm{k}^{*}>0$ consistent with balanced growth, which ensures a unique $\mathrm{u}_{\mathrm{X}}>0$.

It remains to be shown that $\mathrm{u}_{\mathrm{Z}}>0$, which is equivalent to $c^{*}>0$. Multiplying each of competitive profit conditions by the respective $\mathrm{u}_{\mathrm{i}}(\mathrm{i}=\mathrm{X}, \mathrm{Y}, \mathrm{Z})$ and summing up with the use of (2) in equalities, we get the national income identity, $p_{X} u_{X} f+p_{Y} u_{Y} g+u_{Z} j=w+r k$. Substituting into this equation (1c) with equality, (A4) (recall that $\mathrm{w}=\omega(\mathrm{r})$ ) and (A6) gives the solution for $\mathrm{c}^{*}$. Since the right hand side of this expression was shown to be positive above, we have $\mathrm{c}^{*}>0 . \|$

Proof of Proposition 3: For convenience, define $\mathrm{x}(\mathrm{r}, \mathrm{c}, \mathrm{k}) \equiv \mathrm{X} / \mathrm{H}=\mathrm{u}_{\mathrm{x}}(\mathrm{r}, \mathrm{c}, \mathrm{k}) \mathrm{f}\left(\mathrm{k}_{\mathrm{x}}(\mathrm{r})\right)$ and $\mathrm{y}(\mathrm{c}, \mathrm{r}, \mathrm{k}) \equiv \mathrm{Y} / \mathrm{H}=$ $\mathrm{u}_{\mathrm{Y}}(\mathrm{r}, \mathrm{c}, \mathrm{k}) \mathrm{g}\left(\mathrm{k}_{\mathrm{y}}(\mathrm{r})\right)$ and denote $\theta_{\mathrm{Hi}} \equiv \mathrm{w} /\left(\mathrm{p}_{\mathrm{i}} \ell\left(\mathrm{k}_{\mathrm{i}}\right)\right)$ as the corresponding share of labor costs in sector $\mathrm{i}(\mathrm{i}=\mathrm{X}, \mathrm{Y}, \mathrm{Z}$ and $\ell=f, g, j$ ). Utilizing (A3) and (5) and substituting (8) and the definitions of $x$ and y into (1a) and (1b), we obtain the dynamics of $(\mathrm{r}, \mathrm{c}, \mathrm{k})$

$$
\begin{gathered}
\frac{\dot{\mathrm{r}}}{\mathrm{r}}=\left(\frac{\theta_{\mathrm{HZ}}}{\theta_{\mathrm{HX}}-\theta_{\mathrm{HY}}}\right)\left(\frac{\mathrm{r}}{\mathrm{p}_{\mathrm{X}}(\mathrm{r})}-\frac{\mathrm{w}(\mathrm{r})}{\mathrm{p}_{\mathrm{Y}}(\mathrm{r})}+\eta-\delta\right) \\
\frac{\dot{\mathrm{c}}}{\mathrm{c}}=\frac{\dot{\mathrm{C}}}{\mathrm{C}}-\frac{\dot{\mathrm{H}}}{\mathrm{H}}=v^{*}\left(\mathrm{r}^{*}\right)-\mathrm{y}(\mathrm{r}, \mathrm{c}, \mathrm{k})+\eta \\
\frac{\dot{\mathrm{k}}}{\mathrm{k}}=\frac{\dot{\mathrm{K}}}{\mathrm{K}}-\frac{\dot{\mathrm{H}}}{\mathrm{H}}=\left(\frac{\mathrm{x}(\mathrm{r}, \mathrm{c}, \mathrm{k})}{\mathrm{k}}\right)-\mathrm{y}(\mathrm{r}, \mathrm{c}, \mathrm{k})+\eta-\delta
\end{gathered}
$$

The linearized dynamic system of (A7a-c) around the BGP is given by

$$
\left[\begin{array}{c}
\dot{\mathrm{r}} \\
\dot{\mathrm{c}} \\
\dot{\mathrm{k}}
\end{array}\right]=\left[\begin{array}{ccc}
\mathrm{a}_{11} & 0 & 0 \\
\mathrm{a}_{21} & \mathrm{a}_{22} & \mathrm{a}_{23} \\
\mathrm{a}_{31} & \mathrm{a}_{32} & \mathrm{a}_{33}
\end{array}\right]\left[\begin{array}{l}
\mathrm{r}-\mathrm{r}^{*} \\
\mathrm{c}-\mathrm{c}^{*} \\
\mathrm{k}-\mathrm{k}^{*}
\end{array}\right]
$$


where $a_{11}=\frac{r \theta_{H Z}}{\theta_{H X}-\theta_{H Y}}\left(\frac{\partial\left(r / p_{X}\right)}{\partial r}-\frac{\partial\left(w / p_{Y}\right)}{\partial r}\right), \quad a_{22}=\left(\frac{k_{X}-k_{Z}}{k_{X}-k_{Y}}\right) \frac{c g}{j}, \quad a_{23}=\frac{c g}{k_{X}-k_{Y}}$,

$$
a_{32}=\frac{k f}{j k}\left(\frac{k_{Y}-k_{Z}}{k_{X}-k_{Y}}\right)+\frac{k g}{j}\left(\frac{k_{X}-k_{Z}}{k_{X}-k_{Y}}\right), \quad a_{33}=\frac{k g}{k_{X}-k_{Y}}+\left(\frac{f}{k_{X}-k_{Y}}-\frac{x}{k}\right) .
$$

This model has a block recursive structure with a real root $\gamma_{1}=a_{11}$, and with the remaining two roots satisfying the characteristic equation of a $2 \times 2$ subsystem (whose Jacobean matrix evaluated at the BGP is denoted as $\left.\mathrm{J}_{2}{ }^{*}\right)$ :

$$
\gamma^{2}-\operatorname{Tr}\left(\mathrm{J}_{2}{ }^{*}\right) \gamma+\operatorname{Det}\left(\mathrm{J}_{2}{ }^{*}\right)=0
$$

The trace and determinant of the $3 \times 3$ matrix in (A2) are

$$
\begin{gathered}
\operatorname{Det}\left(\mathrm{J}_{2}^{*}\right)=\mathrm{a}_{22} \mathrm{a}_{33}-\mathrm{a}_{23} \mathrm{a}_{23}=\frac{\operatorname{cfg}\left[\mathrm{u}_{\mathrm{Y}} \mathrm{k}_{\mathrm{Y}}+\left(1-\mathrm{u}_{\mathrm{Y}}\right) \mathrm{k}_{\mathrm{Z}}\right]}{\mathrm{jk}\left(\mathrm{k}_{\mathrm{X}}-\mathrm{k}_{\mathrm{Y}}\right)} \\
\operatorname{Tr}\left(\mathrm{J}_{2}^{*}\right)=\mathrm{a}_{22}+\mathrm{a}_{33}=\frac{1}{\left(\mathrm{k}_{\mathrm{x}}-\mathrm{k}_{\mathrm{y}}\right)}\left[\mathrm{g}\left(\mathrm{u}_{\mathrm{y}} \mathrm{k}_{\mathrm{y}}+\left(1-\mathrm{u}_{\mathrm{y}}\right) \mathrm{k}_{\mathrm{x}}\right)+\frac{\mathrm{f}}{\mathrm{k}^{2}}\left(\mathrm{k}_{\mathrm{y}}\left(1-\mathrm{u}_{\mathrm{z}}\right)+\mathrm{u}_{\mathrm{z}} \mathrm{k}_{\mathrm{z}}\right)\right]
\end{gathered}
$$

Using (A5), we have the following two facts:

$$
\operatorname{sign} \mathrm{a}_{11}=\operatorname{sign} \theta_{\mathrm{HX}}-\theta_{\mathrm{HY}}=\operatorname{sign} \mathrm{k}_{\mathrm{Y}}-\mathrm{k}_{\mathrm{X}}, \quad \operatorname{sign} \operatorname{Det}\left(\mathrm{J}_{2}{ }^{*}\right)=\operatorname{sign} \operatorname{Tr}\left(\mathrm{J}_{2}{ }^{*}\right)=\operatorname{sign} \mathrm{k}_{\mathrm{X}}-\mathrm{k}_{\mathrm{Y}}
$$

When $\mathrm{k}_{\mathrm{Y}}>\mathrm{k}_{\mathrm{X}}$, one (real) root will be $\mathrm{a}_{11}>0$ and the other two roots will be the solution to (A9) with $\operatorname{Tr}\left(\mathrm{J}_{2}{ }^{*}\right.$ ) $<0$ and $\operatorname{Det}\left(\mathrm{J}_{2}{ }^{*}\right)<0$ where their real parts will have opposite sign. When $\mathrm{k}_{\mathrm{X}}>\mathrm{k}_{\mathrm{Y}}$, one (real) root will be $a_{11}<0$ and the other two solving (A9) have positive real parts as $\operatorname{Tr}\left(\mathrm{J}_{2}{ }^{*}\right)>0$ and $\operatorname{Det}\left(\mathrm{J}_{2}{ }^{*}\right)>0$. Thus, the system is saddle path stable, regardless of the factor intensity rankings.

In the case where $k_{Y}>k_{X}$, the adjustment process for $r$ is unstable. Thus, $r$ (and hence $p_{X}$ and $p_{Y}$ ) must jump to the corresponding BGP and remain constant along the saddle path. In the case where $\mathrm{k}_{\mathrm{X}}>\mathrm{k}_{\mathrm{Y}}$, the adjustment process for $\mathrm{r}$ is a stabilizing force. Since the costate variables are the derivatives of the value function with respect to the respective state variables, the costate variables are homogeneous of degree $-\sigma$ and $\mathrm{p}_{\mathrm{x}} / \mathrm{p}_{\mathrm{y}} \equiv \mu / \lambda$ is a function of $\mathrm{k}$ alone. Defining this function as $\Lambda(\mathrm{k})=\mathrm{p}_{\mathrm{x}} / \mathrm{p}_{\mathrm{y}}$, we have $\Lambda^{\prime}(\mathrm{k}) \geq 0$ from the concavity of the value function and $\dot{\Lambda}=\Lambda^{\prime} \dot{\mathrm{k}}$. Utilizing (A3), with $\mathrm{k}_{\mathrm{X}}>\mathrm{k}_{\mathrm{Y}}$ we have $\dot{\mathrm{r}}=\alpha \dot{\Lambda}$, where $\alpha>0$. 
Thus, $\Lambda^{\prime}=0$ implies $\dot{\mathrm{r}}=0$. But $\dot{\mathrm{r}}=0$ cannot hold for $\mathrm{r} \neq \mathrm{r}^{*}$ by Proposition 1 , so we must have $\Lambda^{\prime}>0$. $\|$

Proof of Proposition 4: Substituting $v_{\mathrm{H}}^{\mathrm{i}}(\mathrm{t})=v^{*}$ into (12) yield the range of endowments in (14) in part (a). To prove part (b) makes use of the fact that since outputs of all three goods are strictly positive on the interior of the range defined in (14), it is possible to raise or lower $v_{\mathrm{H}}(\mathrm{t})$ in the neighborhood of $v^{*}$ while maintaining full employment and factor price equalization. $\|$

Proof of Proposition 6: From (14), consider a case in which $\mathrm{k}^{\mathrm{i}}=\mathrm{k}^{*}$ and thus there does not exist a factor proportions motivation for trade. A violation of the static $\mathrm{H}-\mathrm{O}$ theorem only requires that there exist values of $v_{\mathrm{H}}{ }^{\mathrm{i}}$ such that $\mathrm{m}_{\mathrm{X}}{ }^{\mathrm{i}} \neq 0$. Such values will exist under the conditions stated in the proposition. The condition $\mathrm{k}_{\mathrm{X}}^{*} \neq \mathrm{k}_{\mathrm{Z}}^{*}$ is necessary for one of the traded goods to be physical capital intensive. The knife edge case with $\mathrm{k}_{\mathrm{X}}^{*}=\mathrm{k}_{\mathrm{Y}}^{*}$ is one in which variations in the growth rate of human capital relative to physical capital have no effect on the physical/human capital ratio available for producing traded goods. \|

Proof of Proposition 8: For the case of $\mathrm{k}_{\mathrm{Y}}>\mathrm{k}_{\mathrm{X}}$, the proof simply follows the arguments in the text. For the case of $k_{X}>k_{Y}$, it remains to show the assertion that when all goods are produced, (i) $\left(p_{X} / p_{Y}\right)^{A}<\left(p_{X} / p_{Y}\right)^{B}$ implies $\mathrm{r}^{\mathrm{A}}<\mathrm{r}^{\mathrm{B}}$ and (ii) $\mathrm{r}^{\mathrm{A}}<\mathrm{r}^{\mathrm{B}}$ implies that $\mathrm{p}_{\mathrm{X}}^{\mathrm{A}}<\mathrm{p}_{\mathrm{X}}^{\mathrm{B}}\left(\mathrm{p}_{\mathrm{X}}^{\mathrm{A}}>\mathrm{p}_{\mathrm{X}}^{\mathrm{B}}\right)$ if $\mathrm{k}_{\mathrm{X}}>\mathrm{k}_{\mathrm{Z}}\left(\mathrm{k}_{\mathrm{X}}>\mathrm{k}_{\mathrm{Z}}\right)$ on $\left[\mathrm{r}^{\mathrm{A}}, \mathrm{r}^{\mathrm{B}}\right]$.

Utilizing (A1) and (A3), we can derive

$$
\frac{d p_{X} / p_{Y}}{d r}=\frac{p_{X}}{p_{Y}} \frac{j\left(k_{X}-k_{Y}\right)}{p_{X} p_{Y} f g}
$$

which implies (i). Then (ii) follows immediately from the differentiation results in (A3). $\|$ 


\section{Endnotes}

1. Lucas $(1988,1993)$ spurred interest in this area with papers arguing that human capital accumulation is the "engine of development" and a critical factor in explaining the East Asian "miracles" of growth. Romer (1990) and Barro (1991) provide empirical support for the importance of human capital to economic growth in cross-sectional studies. Evidence in support of the role of human capital for the case of Taiwan was found by Tallman and Wang (1994) who calculate that growth in the stock of human capital accounted for fully $45 \%$ of output growth over the period of their study. Young (1995) argues that nearly all of output growth in the East Asian economies can be accounted for by traditional measures of growth in inputs when those inputs include human capital.

2. A second type of model assumes that there are differences across countries in parameters such as savings rates (Smith (1984)), tax policies (Baxter (1992)), or time preferences (Stiglitz (1970)) which lead countries to have different autarkic steady states. In these models, the emphasis is on how differences in these parameters influence steady state values of factor prices and trade patterns. For example, Smith (1984) shows that in models of capital accumulation with fixed savings rates, the high savings rate country will export the capital intensive good in the long run. Stiglitz (1970) analyzes the case in which patience is reflected in different rates of time preference with infinitely lived consumers and shows that the patient country will export the capital intensive good in the steady state. At least one country will specialize in production in the steady state in the Stiglitz model, and international factor prices will not equalize. In contrast, Galor and Lin (1997) show that in an overlapping generations model, differences in rates of time preference may be consistent with factor price equalization in the long run equilibrium even though the patient country still exports the capital intensive good. Bond and Trask (1997) examine how technological differences affect the long run trade pattern in a variant of the model in this paper.

3.Two possibilities arise regarding the steady state. One is that the country's capital supplies converge to the same capital/labor ratio, so that factor endowments based trade is eliminated as countries approach the steady state (e.g., Findlay (1970, 1995, Ch 2), Deardorff and Hansen (1978)). Another possibility is that the country's factor supplies converge to different ratios in steady state, allowing international trade (and differences in per capita income) to persist in the steady state. (e.g. Ventura (1997)). Whether or not the economies converge to the same steady state under trade, there can be factor proportions based trade along the transition path to the steady state.

4. We treat education as a private good, whose returns are fully internalized by the owner. Grossman and Helpman (1991, Chapter 5) consider the case in which there are external effects from the development of new products and examine accumulation of two "factors": technology and a general capital. Their model differs from ours in the sense that knowledge is the engine of growth due to the presence of scale economies. Also, we assume that all workers experience the same increase in effective units of labor. In contrast, Stokey (1996) considers a model in which labor is heterogenous and classified as skilled or unskilled. The economy accumulates human capital or skilled labor through the transformation of unskilled labor.

5. In this section, we establish the existence of a unique BGP in which the control variables are in the interior of the feasible set. It is possible, however, that for some initial values of $\mathrm{K}$ and $\mathrm{H}$ there will be regions of the path for which $\mathrm{u}_{\mathrm{X}}=\mathrm{s}_{\mathrm{X}}=0$ or $\mathrm{u}_{\mathrm{Y}}=\mathrm{s}_{\mathrm{Y}}=0$. These cases can readily be handled by incorporating the constraints on control variables into $\mathrm{P}$ and making the appropriate modifications in the Hamiltonian. For a discussion of the validity and sufficiency of the transversality conditions, (3f) see Bond, Wang, and Yip (1996). 
6. The current value Hamiltonian for this problem can be written as:

$$
\max _{\omega_{c}} \frac{\mathrm{C}^{1-\sigma}}{1-\sigma}+\gamma\left[\left(1-\mathrm{u}_{\mathrm{X}}-\mathrm{u}_{\mathrm{Y}}\right) \mathrm{Hj}\left(\mathrm{k}_{\mathrm{Z}}\right)-\mathrm{C}\right]+\lambda\left[\mathrm{u}_{\mathrm{Y}} \mathrm{Hg}\left(\mathrm{k}_{\mathrm{Y}}\right)-\eta \mathrm{H}\right]+\mu\left[\mathrm{u}_{\mathrm{X}} \mathrm{Hf}\left(\mathrm{k}_{\mathrm{X}}\right)-\delta \mathrm{K}\right] .
$$

7. Since we will be focusing on distributions of factor supplies across countries such that factor prices are equalized by trade, the assumption that trade is balanced will not be restrictive.

8. Trefler (1993) argues that a simple modification of the traditional H-O model may fit the data well once factor endowments are adjusted to reflect international productivity differences. Our version of factor price equalization is consistent with this empirical finding.

7. Note that this price version imposes some restrictions on the technology because it requires that there be no factor intensity reversals on the region being considered. 